\title{
Zinc, Carnosine, and Neurodegenerative Diseases
}

\author{
Masahiro Kawahara *, Ken-ichiro Tanaka and Midori Kato-Negishi \\ Department of Bio-Analytical Chemistry, Faculty of Pharmacy, Musashino University, 1-1-20 Shinmachi, \\ Nishitokyo-shi, Tokyo 202-8585, Japan; k-tana@musashino-u.ac.jp (K.-i.T.); \\ mnegishi@musashino-u.ac.jp (M.K.-N.) \\ * Correspondence: makawa@musashino-u.ac.jp; Tel./Fax: +81-42-468-8299
}

Received: 14 November 2017; Accepted: 23 January 2018; Published: 29 January 2018

\begin{abstract}
Zinc (Zn) is abundantly present in the brain, and accumulates in the synaptic vesicles. Synaptic $\mathrm{Zn}$ is released with neuronal excitation, and plays essential roles in learning and memory. Increasing evidence suggests that the disruption of $\mathrm{Zn}$ homeostasis is involved in various neurodegenerative diseases including Alzheimer's disease, a vascular type of dementia, and prion diseases. Our and other numerous studies suggest that carnosine ( $\beta$-alanyl histidine) is protective against these neurodegenerative diseases. Carnosine is an endogenous dipeptide abundantly present in the skeletal muscles and in the brain, and has numerous beneficial effects such as antioxidant, metal chelating, anti-crosslinking, and anti-glycation activities. The complex of carnosine and $\mathrm{Zn}$, termed polaprezinc, is widely used for $\mathrm{Zn}$ supplementation therapy and for the treatment of ulcers. Here, we review the link between $\mathrm{Zn}$ and these neurodegenerative diseases, and focus on the neuroprotective effects of carnosine. We also discuss the carnosine level in various foodstuffs and beneficial effects of dietary supplementation of carnosine.
\end{abstract}

Keywords: zinc; copper; synapse; amyloid; apoptosis; ER stress; food analysis

\section{Introduction}

Zinc ( $\mathrm{Zn})$ is an essential trace element abundantly present after iron (Fe). It is a co-factor of more than 300 enzymes or metalloproteins, and plays a critical role in many functions including cell division, immune system, protein synthesis, and DNA synthesis [1,2]. Increasing evidence suggests that $\mathrm{Zn}$ acts as a second messenger in various biological systems, similar to calcium (Ca) [3]. Zn reportedly binds with a Zn-binding motif or metal-responsive element of about $10 \%$ of all proteins and regulates their levels of expression by recent bioinformatics research of the human genome [4].

Given these crucial functions in humans, Zn deficiency causes various adverse effects [5-8]. $\mathrm{Zn}$ deficiency in childhood causes the retardation of mental and physical development, learning disabilities, dwarfism, and dysfunction of the immunological system in humans. Because $\mathrm{Zn}$ is essential for olfaction and taste, Zn deficiency leads to learning, taste, and olfactory disorders in adults. Moreover, Zn deficiency is related to levels of depression and stress.

It was recommended that the estimated average requirement (EAR) of $\mathrm{Zn}$ is $12 \mathrm{mg} /$ day for adult males and $9 \mathrm{mg}$ /day for adult females by the Japanese Ministry of Health, Labour and Welfare. Although daily intake of $\mathrm{Zn}$ is estimated to be $10-15 \mathrm{mg}$, many patients suffer from a mild $\mathrm{Zn}$ deficiency because $\mathrm{Zn}$ intake and absorption are distinctive. The bioavailability of $\mathrm{Zn}$ is influenced by many food constituents such as phytates and fibers in plants, which form poorly soluble complexes with Zn and inhibit its gastrointestinal absorption [9]. Yasuda and Tsutui reported that approximately $20 \%$ or more of the elderly and children in Japan suffers from Zn deficiency [10]. The World Health Organization reported that $1.4 \%$ ( 0.8 million) of deaths worldwide are attributed to Zn deficiency [11]. Therefore, supplementation is important for the prevention and treatment of $\mathrm{Zn}$ deficiency. $\mathrm{Zn}$ supplementation therapy is used in the treatment of pressure ulcers, measles, and taste disorders [12-14]. A complex of 
$\mathrm{Zn}$ and carnosine ( $\beta$-alanyl histidine), termed polaprezinc, is widely used for this purpose [15]. Polaprezinc is also used for protecting the mucosa against ulcerations and for the treatment of Helicobacter pylori-associated gastritis [16,17].

Carnosine is an endogenou dipeptide [18]. Carnosine is small and water-soluble. Carnosine and its analogues (homocarnosine and anserine) (Figure 1) exist in many organisms such as birds, fish, and mammals, including humans. It is abundantly present in skeletal muscles, but is also observed in the stomach, kidneys, cardiac muscle, and brain. Thus, daily foods such as meats or fish contain considerable amounts of carnosine.

Carnosine has various advantageous characteristics, such as anti-glycation, anti-stress, and antioxidant properties, hydroxyl radical scavenging, maintenance of $\mathrm{pH}$-balance, and chelation of metals including divalent zinc ion $\left(\mathrm{Zn}^{2+}\right)$ and bivalent copper ion $\left(\mathrm{Cu}^{2+}\right)$ (Figure 2) [19]. Carnosine is one of the most abundant small-molecule compounds in skeletal muscle, with concentrations similar to those of creatine and adenosine triphosphate (ATP). Carnosine contributes to the physicochemical buffering of lactate caused by exercise in skeletal muscles and has anti-fatigue effects. It is possible that carnosine contributes to the regulation of $\mathrm{Zn}$ availability in the brain [9]. Ours and other numerous studies indicate that carnosine is neuroprotective against various neurodegenerative diseases such as Alzheimer's disease (AD) [20], the vascular type of senile dementia (VD) [21], prion diseases [22], autism spectrum disorder [23], and Gulf War syndrome [24]. Furthermore, supplementation therapy with carnosine and anserine is reported to be effective for improving cognitive impairment in the elderly [25].

Here, with a focus on the neuroprotective functions of carnosine, we review the link between $\mathrm{Zn}$ and neurodegenerative diseases, and investigate the neuroprotective roles of carnosine in terms of nutrients as a drug for these neurodegenerative diseases. We also discuss the levels of carnosine in foodstuffs based on our developed convenient quantitative analysis method using high performance liquid chromatography (HPLC).

(a)

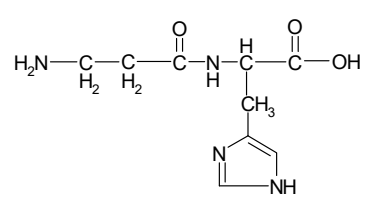

(b)

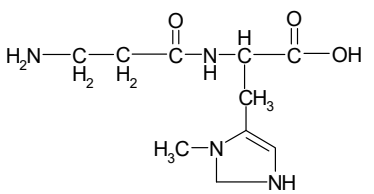

(c)

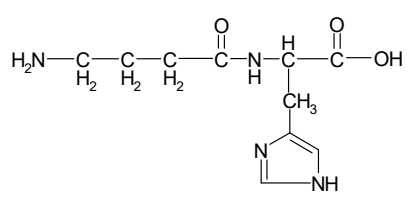

Figure 1. Structures of carnosine and its analogues: (a) carnosine (b) anserine (c) homocarnosine.

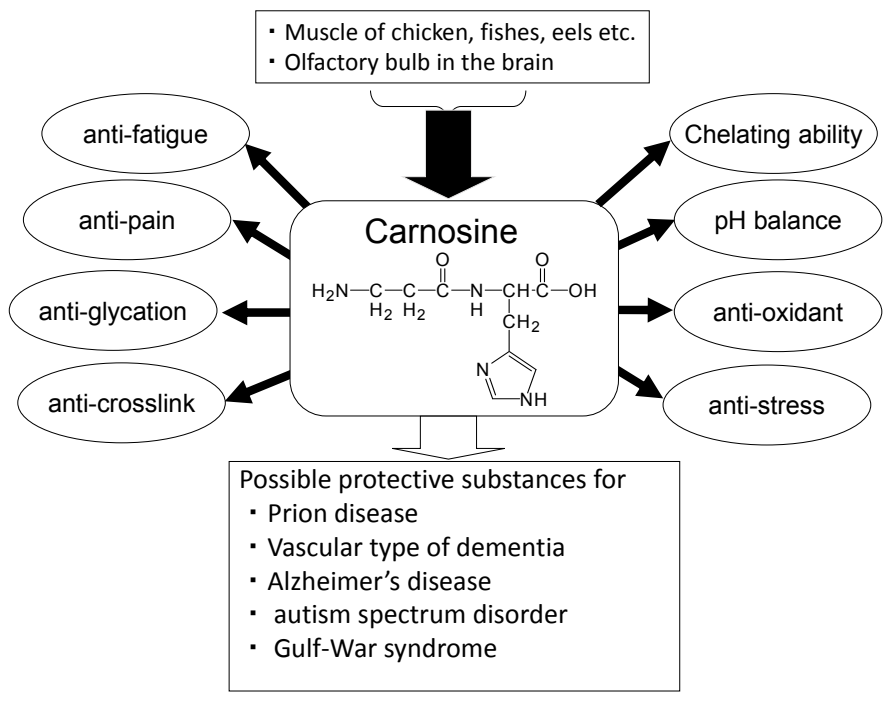

Figure 2. Beneficial effects of carnosine. 


\section{Roles of Zinc in the Brain}

$\mathrm{Zn}$ is abundantly present in the testes, muscle, liver, and brain tissues, and total $\mathrm{Zn}$ content is approximately $2 \mathrm{~g}$. $\mathrm{Zn}$ is accumulated in the hippocampus, amygdala, cerebral cortex, thalamus, and olfactory cortex in the brain [26]. $\mathrm{Zn}$ is estimated to be present as 70-90 ppm $(\sim 20 \mu \mathrm{M})$ in the hippocampus [27]. $\mathrm{Zn}$ in the brain binds to metalloproteins or enzymes; however, approximately $10 \%$ or more $\mathrm{Zn}$ is stored in the presynaptic vesicles of glutamatergic excitatory neurons as free zinc ions $\left(\mathrm{Zn}^{2+}\right)$. During neuronal excitation, the chelatable $\mathrm{Zn}^{2+}$ is secreted into synaptic clefts from vesicles with glutamate. The secreted $\mathrm{Zn}$ reportedly regulates the overall excitability of the brain by binding with various neurotransmitter receptors such as $N$-methyl-D-aspartate (NMDA)-type glutamate receptors, amino-3-hydroxy-5-methyl-4-isoxazolepropionic acid (AMPA)-type glutamate receptors, $\gamma$-aminobutyric acid (GABA) receptors, and glycine receptors [28]. Ueno et al. reported that secreted $\mathrm{Zn}^{2+}$ modulates spatio-temporal information in the hippocampus [29]. Thus, the secreted $\mathrm{Zn}$ is essential for synaptic plasticity, information processing, and memory formation. Indeed, $\mathrm{Zn}$ is reported to be essential for the induction of long-term potentiation (LTP) in the mossy fiber, a form of synaptic information storage [30]. It is possible that secreted $\mathrm{Zn}^{2+}$ has neuromodulators roles. Since $\mathrm{Zn}$ has been shown to generate neural inhibition, $\mathrm{Zn}$ can modulate the activity of the neighboring synapses by diffusing into synaptic clefts to the adjacent synapses in a distance-dependent manner. A similar phenomenon was reported as 'lateral inhibition', which caused the contrast of signals underlying the mechanism of synaptic plasticity [31].

Similar to $\mathrm{Zn}^{2+}, \mathrm{Cu}^{2+}$ was also reported to exist in synaptic vesicles. During neuronal excitation, $\mathrm{Cu}^{2+}$ is secreted into the synaptic cleft [32]. The secreted $\mathrm{Cu}^{2+}$ modulates neuronal excitability by binding to various receptors, including the GABA receptor, AMPA-type glutamate receptor, and NMDA-type glutamate receptor. The size of the synaptic cleft is estimated to be $20 \mathrm{~nm}$ in height and $120 \mathrm{~nm}$ in width, and is composed of $\sim 1 \%$ of the total extracellular volume in the brain [33]. Considering its small size, it is more than plausible that the levels of neurotransmitters or metals are high in the synapse. Indeed, the concentration of glutamate is estimated to reach the $\mathrm{mM}$ range after neuronal depolarization in the synaptic cleft. Although the level of $\mathrm{Zn}$ in cerebrospinal fluid (CSF) is less than $1 \mu \mathrm{M}$, its level in the synaptic clefts is reported to be 1-100 $\mu \mathrm{M}$ [34]; meanwhile, the level of $\mathrm{Cu}^{2+}$ in the synaptic clefts is reported to be 2-15 $\mu \mathrm{M}$ [35]. Since $\mathrm{Zn}^{2+}$ and $\mathrm{Cu}^{2+}$ compete for entry into the body or for many binding proteins, it is possible that excess $\mathrm{Zn}$ can also lead to $\mathrm{Cu}$ dyshomeostasis.

Carnosine is reported to be synthesized in astrocytes and oligodendrocytes. It exists in olfactory bulb neurons and in glial cells, and is secreted from glial cells into the synaptic cleft [36]. Thus, it is highly possible that carnosine regulates $\mathrm{Zn}$ and $\mathrm{Cu}$ homeostasis in synaptic clefts. The hypothetical roles of $\mathrm{Zn}^{2+}$ and $\mathrm{Cu}^{2+}$ in the synapse are displayed in Figure 3.

$\mathrm{Zn}$ homeostasis is regulated by three factors, besides carnosine; metallothioneins, $\mathrm{Zn}$ transporters $(\mathrm{ZnT})$, and Zrt-, Irt-like protein (ZIP) Zn transporters [37,38]. Metallothioneins are ubiquitous metal-binding proteins composed of 68 amino acids. These proteins possess 20 cysteine residues, and bind seven metal atoms including $\mathrm{Cu}$, cadmium $(\mathrm{Cd})$, and $\mathrm{Zn}$. Among three types of metallothioneins: MT-1, MT-2, and MT-3, MT-3 is mainly observed in the central nervous system. However, MT-1 and MT-2 generally exist in the whole body.

There are 14 types of ZnTs in mammals. ZnTs decrease intracellular Zn by facilitating Zn efflux from cells. They are encoded with the solute carrier (SLC30) gene family. ZnT-1 has a pivotal role in Zn efflux and is involved in protection from excess Zn. ZnT-1 and ZnT-3 are co-localized with chelatable $\mathrm{Zn}$ in the brain. ZnT-3 transports $\mathrm{Zn}$ into synaptic vesicles, and maintains high $\mathrm{Zn}$ concentrations in these vesicles.

ZIP Zn transporters transport $\mathrm{Zn}$ from extracellular compartments to those which are intracellular and increase cytosolic Zn. ZIP Zn transporters are encoded by fourteen SLC39 genes. ZIP transporters are also located in the membranes of the Golgi apparatus or the endoplasmic reticulum (ER), and regulate $\mathrm{Zn}$ in subcellular organelles. Genetic defects of $\mathrm{Zn}$ transporter mutations produce severe diseases such as Ehlers-Danlos syndrome [39]. 


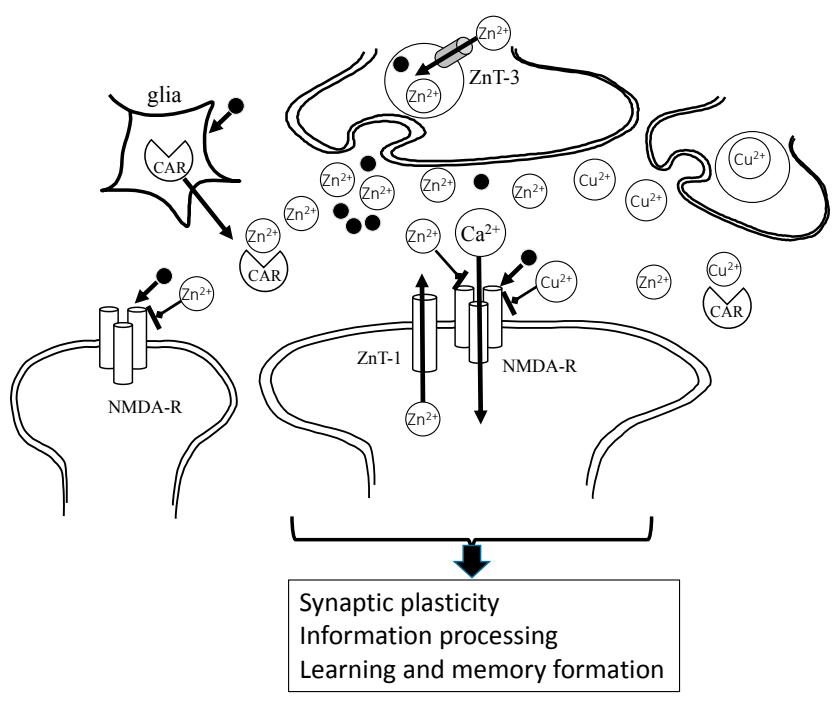

Figure 3. Under physiological conditions, $\mathrm{Zn}^{2+}$ and glutamate are released from presynaptic vesicles, and inhibit NMDA-type glutamate receptors (NMDA-Rs) and regulate other receptors. $\mathrm{Zn}^{2+}$ spilled over into the neighboring synapse, modulating excitability. It is possible that $\mathrm{Zn}$ is essential in the maintenance of synaptic plasticity and the formation of memory. $\mathrm{Cu}^{2+}$ is also secreted and acts in a similar manner to $\mathrm{Zn}^{2+}$. Carnosine binds to $\mathrm{Zn}^{2+}$, as well as $\mathrm{Cu}^{2+}$, and regulates these concentrations at the synapse. $\mathrm{Zn}^{2+}$ : divalent zinc ion; $\mathrm{Cu}^{2+}$ : bivalent copper ion; $\mathrm{Ca}^{2+}$ : divalent calcium ion; CAR: carnosine; ZnT-1: zinc transporter $1, \bullet$ glutamate.

Furthermore, the excess or deficiency of $\mathrm{Zn}$, namely, the dyshomeostasis of $\mathrm{Zn}$ in the brain, is considered to have relationships with the pathogenesis of several neurodegenerative diseases including AD, VD, prion diseases, and amyotrophic lateral sclerosis (ALS) [40-43].

\section{Zinc, Carnosine and Alzheimer's Disease}

\subsection{The Amyloid Hypothesis}

In Japan, elderly adults aged more than 75 years represented 10\% of the total population in 2013. Therefore, approximately 4 million people are affected by senile dementia and this is a number that continues to grow annually.

Most senile dementia is divided into AD, VD, and dementia with Lewy bodies (DLB). AD accounts for more than half the cases of senile dementia. Although AD was first reported in 1906, the number of AD patients was estimated to be more than 5 million in the U.S. in 2016. AD is characterized by the deposition termed senile plaques and neurofibrillary tangles (NFTs). The selective loss of synapses and neurons in the hippocampal and cerebral cortical regions is also observed [44]. The major component of NFTs is phosphorylated tau protein, and that of senile plaques is $\beta$-amyloid protein $(\mathrm{A} \beta \mathrm{P})$. The primary factor of $\mathrm{AD}$ pathogenesis remains controversial. The accumulation of tau protein and/or the degeneration of cholinergic neurons might occur during the pathogenesis. However, the idea of the amyloid cascade hypothesis, which suggests that the accumulation of $A \beta P$ and the consequent neurodegeneration play a central role in $\mathrm{AD}$ is supported by many researchers $[45,46]$. $\mathrm{A} \beta \mathrm{P}$ is a small peptide composed of $39-43$ amino acid residues. $\mathrm{A} \beta \mathrm{P}$ is secreted from a large precursor protein (amyloid precursor protein; APP) in the $N$-terminal by $\beta$-secretase $(\beta$-site APP cleaving enzyme; $\mathrm{BACE}$ ), which is followed by the intra-membrane cleavage of its $\mathrm{C}$-terminal by $\gamma$-secretase. The truncated $\mathrm{A} \beta \mathrm{Ps}$, such as $\mathrm{A} \beta \mathrm{P}(1-40)$, the first 40 amino acid residues, or $\mathrm{A} \beta \mathrm{P}(1-42)$ are produced by the different $\mathrm{C}$-terminal cleavage of APP (Figure 4). Secreted A $\beta P$ is generally degraded by specific proteases such as neprilysin. It was reported that APP mutations and A $\beta P$ metabolism are associated with $\mathrm{AD}$ from genetic studies of early-onset cases of familial AD indicated in [47]. It was also revealed 
that mutations in the presenilin genes account for the majority of cases of early-onset familial AD. Presenilins are reported to be one of the $\gamma$-secretases. Their mutations also influence the production of truncated $\mathrm{A} \beta \mathrm{P}$ and its neurotoxicity.
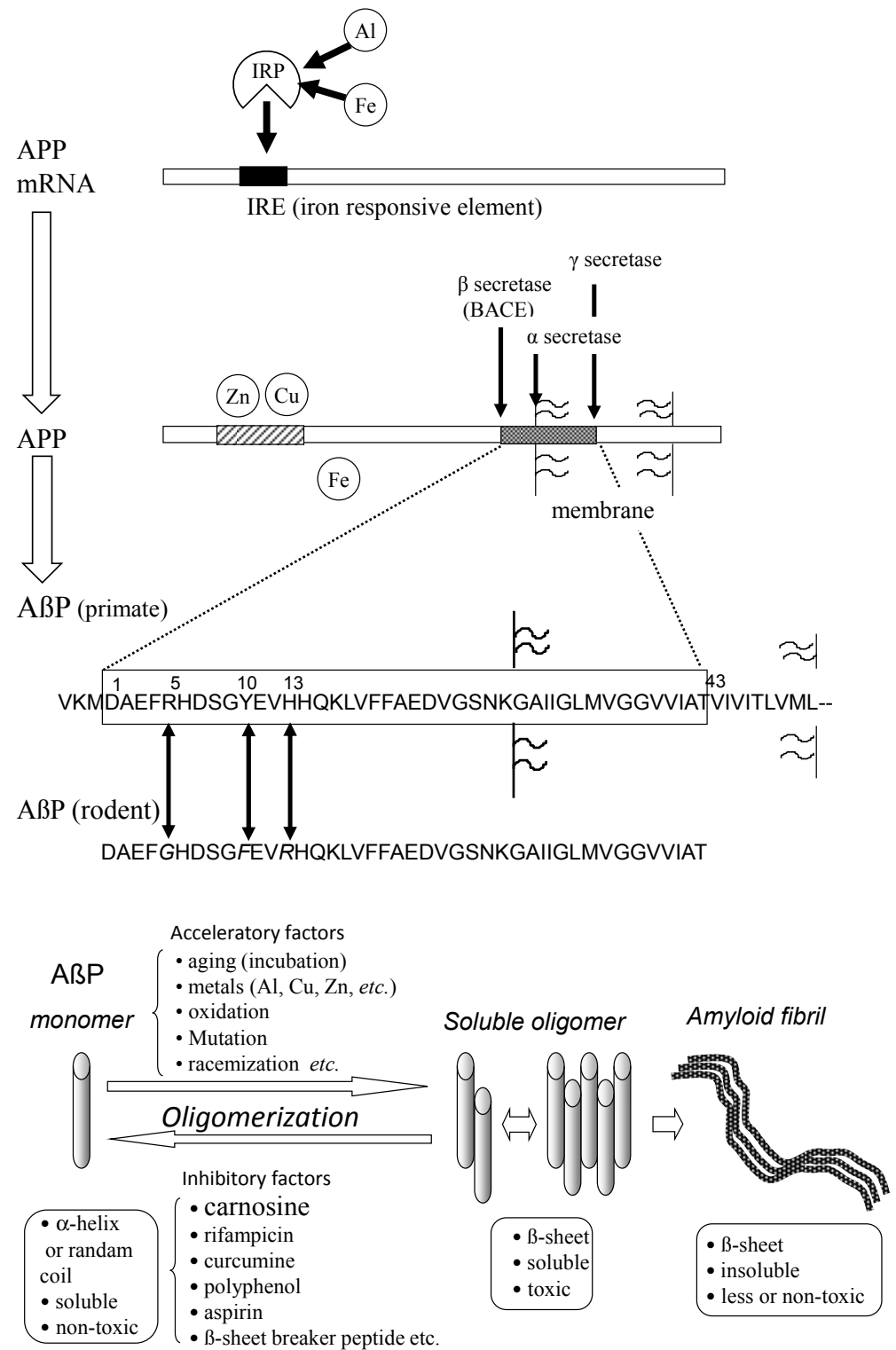

Figure 4. Secretion and oligomerization of A $\beta P$. A $\beta P$ is secreted from APP by $\beta$-secretase (BACE) and by $\gamma$-secretase. The expression of APP is regulated by Fe and may be influenced by Al. APP also binds to $\mathrm{Cu}$ and $\mathrm{Zn}$. Three amino acids $\left(\mathrm{Arg}^{5}, \mathrm{Tyr}^{10}\right.$, and His ${ }^{13}$ ) of human $\mathrm{A} \beta P$ are substituted in rodent $\mathrm{A} \beta \mathrm{P}$. Under aging conditions or in the presence of acceleratory factors, monomeric $\mathrm{A} \beta \mathrm{P}$ with random or $\alpha$-helix structures self-aggregates and forms several types of oligomers (SDS-soluble oligomers, amyloid $\beta$-derived diffusible ligands, globulomers, protofibrils) before finally forming insoluble aggregates (amyloid fibrils). The monomeric and fibril aggregates are relatively nontoxic; however, oligomeric soluble A $\beta$ Ps are toxic. APP: amyloid precursor protein; mRNA: messenger ribonucleic acid; $A \beta P$ : $\beta$-amyloid protein; Al: aluminum; Fe: iron; IRP: iron regulatory protein.

In 1990, Yankner et al. found that A $\beta P(1-40)$ caused the toxicity of cultured rat hippocampal neurons [48]. Although these findings were controversial, the neurotoxicity of A $\beta P$ was demonstrated to be influenced by its oligomerization and subsequent conformational change [49]. A $\beta \mathrm{P}$ has a tendency to self-aggregate into oligomers. A $\beta$ P exists as a monomeric protein when freshly prepared 
and dissolved in an aqueous solution, and exhibits a random coil structure. However, A $\beta$ P forms aggregates (oligomers) after incubation at $37^{\circ} \mathrm{C}$ for several days (aging). The oligomer $\mathrm{A} \beta \mathrm{P}$ possess $\beta$-pleated sheet structures and finally forms insoluble aggregates (amyloid fibrils). Neurotoxicity of $\mathrm{A} \beta \mathrm{P}$ was reported to be enhanced during the aging process [50].

\subsection{Metals and Amyloid}

$A \beta P$ is reportedly secreted in the CSF of non-dementia aged individuals, as well as young individuals [51]. Therefore, not only the amount of $\mathrm{A} \beta \mathrm{P}$, acceleratory factors, or inhibitory factors of its oligomerization may be essential in $\mathrm{AD}$ pathogenesis. $\mathrm{A} \beta \mathrm{P}$ oligomerization is influenced by peptide concentrations, $\mathrm{pH}$, solvent composition, and temperature. The oxidation, mutation, and racemization of $\mathrm{A} \beta \mathrm{P}$ can affect it [52]. $\mathrm{Zn}$ and other trace elements such as aluminum $(\mathrm{Al}), \mathrm{Cu}$, and iron $(\mathrm{Fe})$ are important accelerating factors. The amino acid sequences of humans and rodents $A \beta P$ are similar, and rodent $\mathrm{A} \beta \mathrm{P}$ is different from primate $\mathrm{A} \beta \mathrm{P}$ by only three amino acids ( $\mathrm{Arg}^{5}$, $\mathrm{Tyr}^{10}$, and $\mathrm{His}^{13}$ ). However, the accumulation of $A \beta P$ is rarely observed in the rodent brains. Indeed, rodent $A \beta P$ has less of a tendency to aggregate compared with primate $A \beta P$ in vitro [53]. Interestingly, all of these three amino acids have the ability to bind metals. Bush et al. found that $\mathrm{Zn}$ induced the oligomerization of $\mathrm{A} \beta \mathrm{P}$, even the low concentrations ( $300 \mathrm{nM}$ ) [54]. They also reported that $\mathrm{Cu}$ remarkably enhanced the $\mathrm{A} \beta \mathrm{P}$ aggregation [55]. Zn binds to three histidine residues $\left(\mathrm{His}^{6}{ }^{6} \mathrm{His}^{13}\right.$, and $\mathrm{His}^{14}$ ) and /or to carboxyl group of $A^{1} p^{1}$ of $A \beta P[56]$.

However, the oligomerization of $A \beta P$ by metals is still controversial. The morphologies of $A \beta P$ oligomers with $\mathrm{Al}, \mathrm{Cu}, \mathrm{Fe}$, and $\mathrm{Zn}$ are quite different [57]. Metals such as $\mathrm{Al}, \mathrm{Cu}, \mathrm{Fe}$, and $\mathrm{Zn}$ alter the oligomerization and toxicity of $\mathrm{A} \beta \mathrm{P}$ in a different manner [58]. Cu-oligomerized $\mathrm{A} \beta \mathrm{P}$ is more toxic compared with $\mathrm{Zn}$-oligomerized A $\beta \mathrm{P}$ [59]. We found that $\mathrm{Al}$ caused more marked oligomerization than other metals, such as $\mathrm{Zn}, \mathrm{Cu}, \mathrm{Fe}$, and cadmium (Cd) [60]. Furthermore, Al-aggregated A $\beta$ Ps bind tightly to the surfaces of cultured neurons and form fibrillary deposits several days after exposure, compared to Zn-aggregated A $\beta$ Ps.

Meanwhile, $\mathrm{Zn}$ can attenuate A $\beta$ P-induced neurotoxicity and contributes to $\mathrm{AD}$ as a protector [40]. Various adverse effects after A $\beta P$ exposure are reported, such as the induction of cytokines, the induction of ER stress, the production of reactive oxygen species, and the abnormal increase of intracellular calcium levels $\left(\left[\mathrm{Ca}^{2+}\right]_{\mathrm{i}}\right)[61]$. Although these effects may interact with each other, the disruption of $\mathrm{Ca}^{2+}$ homeostasis could be the primary adverse event of $A \beta P$ neurotoxicity given that $\mathrm{Ca}^{2+}$ is involved in numerous cellular functions [62]. Arispe et al. first demonstrated that A $\beta P$ forms pore-like channel structures on artificial lipid bilayers, which are permeable to $\mathrm{Ca}^{2+}$ and other cations, multilevel, voltage-independent, and long-lasting [63]. We found that A $\beta P$ forms pore-like channels on neuronal membranes [64], and demonstrated that $\mathrm{A} \beta \mathrm{P}$ caused the increase of intracellular $\mathrm{Ca}^{2+}$ levels of cultured neurons using fura- $2 \mathrm{Ca}^{2+}$ imaging [65]. Based on these results, the 'amyloid channel hypothesis' was demonstrated; which suggests that the direct incorporation of A $\beta$ Ps on neuronal membranes and the subsequent increase of intracellular $\mathrm{Ca}^{2+}$ through the amyloid channels might be the primary event in A $\beta$ P neurotoxicity [66]. A $\beta P$ might share the similar mechanism underlying the toxicity of various antimicrobial or antifungal peptides that also exhibit channel-forming activity and cell toxicity in this respect [67]. We and other researchers found that the channel activity was inhibited by the exposure to $\mathrm{Zn}^{2+}$, and recovered by $o$-phenanthroline, a $\mathrm{Zn}$ chelator $[64,68]$. Since His residues are exposed to inner surfaces of amyloid channels, $\mathrm{Zn}$ can bind to these His residues and protect neurons from A $\beta P$-induced Ca dyshomeostasis [69]. Therefore, the role of $\mathrm{Zn}$ in the pathogenesis of $\mathrm{AD}$ is still controversial and $\mathrm{Zn}$ may act as a contributor of $\mathrm{AD}$ pathogenesis, as well as a protector. In this context, $\mathrm{Zn}$ might play a role like Janus, the ancient Roman god of doorways, who is depicted with two different faces [40].

Moreover, APP is a metal binding protein that has two $\mathrm{Cu}$ and/or $\mathrm{Zn}$ binding domains in its $\mathrm{N}$-terminal. APP possesses the ability to reduce $\mathrm{Cu}^{2+}$ to $\mathrm{Cu}^{+}$. $\mathrm{Cu}$ and $\mathrm{Zn}$ influence the expression and processing of APP and enhance A $\beta$ P production [70,71]. $\mathrm{Cu}$ induces the dimerization and trafficking 
of APP from the ER to neurites. APP also regulates Fe homeostasis. APP mRNA possesses an iron responsive element (IRE). It means that the expression of APP is regulated by Fe, as well as ferritin (iron storage protein) [72]. In contrast, APP binds to ferroportin, which controls Fe efflux [73]. Therefore, APP is suggested to regulate the homeostasis of metals including $\mathrm{Zn}, \mathrm{Cu}$, and Fe.

\subsection{Carnosine as an Anti-Crosslinker of $A \beta P$}

Molecules that inhibit the oligomerization of $\mathrm{A} \beta \mathrm{P}$ may be candidates for preventive AD therapeutics. Several compounds such as rifampicin, curcumin, and transthyretin have been reported to inhibit the oligomerization of $\mathrm{A} \beta \mathrm{P}$ [52]. A small peptide composed of five amino acids, called a $\beta$-sheet breaker peptide, markedly blocks A $\beta$ P oligomerization [74].

Carnosine has an anti-crosslinking ability, as shown in Figure 2, and inhibits the oligomerization of proteins such as $\alpha$-crystalline [75]. Thus, $N$-acetyl carnosine has been used for the treatment of cataracts [76]. Increasing evidence indicates that carnosine inhibits the oligomerization of $\mathrm{A} \beta \mathrm{P}$ and blocks its neurotoxicity $[77,78]$. Corona et al. demonstrated that orally administered carnosine inhibits the accumulation of $\mathrm{A} \beta \mathrm{P}$, and prevents learning deficits in a murine model of AD [20]. Moreover, histidine and carnosine are significantly reduced in the CSF of AD patients [79]. Therefore, carnosine may well play neuroprotective roles against AD.

\section{Zinc, Carnosine, and Vascular Type of Dementia}

\subsection{Zinc and Ischemia-Induced Neuronal Death}

VD accounts for about one-third of senile dementia cases in Japan. Its risk factors are high blood pressure and diabetes. The interruption of blood flow causes the oxygen-glucose deprivation and membrane depolarization after transient global ischemia or stroke [80]. Thereafter, an excess release of glutamate into synaptic clefts causes the overstimulation of the glutamate receptor and the entry of large quantities of $\mathrm{Ca}^{2+}$ into neurons, and triggers the death of pyramidal neurons in the hippocampus, which are crucial in memory formation.

Zn plays a crucial role in the neuronal death after ischemia and the pathogenesis of VD [81,82]. Excess $\mathrm{Zn}$ can be neurotoxic in spite of its importance in the brain. The concentration of $\mathrm{Zn}$ in synaptic clefts is estimated to be 1-100 $\mu \mathrm{M}$. However, a considerable amount of $\mathrm{Zn}$ (up to $300 \mu \mathrm{M}$ ) is co-released with glutamate into synaptic clefts during ischemic conditions [27]. Koh et al. demonstrated that $\mathrm{Zn}$ accumulates in apoptotic neurons in the hippocampus after ischemia [83]. The membrane-impermeable Zn chelator (calcium ethylene diamine tetraacetic acid (Ca-EDTA)) protects hippocampal neurons after ischemia and reduces infarct volume [84]. Zn can cause mitochondrial failure and oxidative stress [85].

\subsection{Molecular Mechanism of Zn-Induced Neurotoxicity: GT1-7 Cells as an In Vitro Model System}

We investigated the molecular mechanism underlying $\mathrm{Zn}$ neurotoxicity and the protective mechanism of carnosine in immortalized hypothalamic neurons (GT1-7 cells). We found that Zn causes the death of GT1-7 cells in a dose-dependent manner [86]. The degenerated GT1-7 cells exhibited apoptotic characteristics including DNA fragmentation, as well as terminal deoxynucleotidyl transferase-mediated biotinylated uridine triphosphate (UTP) nick-end labeling (TUNEL)-positive. GT1-7 cells were revealed to be much more sensitive to Zn and exhibited much lower viability after Zn exposure compared with other neuronal cells, such as primary cultured rat hippocampal neurons, B-50 neuroblastoma cells, and PC-12 cells [87]. The GT1-7 cells were developed by Mellon et al. from mouse hypothalamic neurons by genetically targeted tumorigenesis [88]. The cells possess neuronal characteristics, such as the extension of neurites and expression of neuron-specific proteins or receptors. Meanwhile, the GT1-7 cells possess low levels of ionotropic glutamate receptors and are not subject to glutamate toxicity. These properties imply that the GT1-7 cell line is a good model system for the investigation of $\mathrm{Zn}$-induced neurotoxicity. 
Using GT1-7 cells, it was found that pyruvate, citrate, the antagonists of $\mathrm{Ca}^{2+}$ channels (nifedipine, conotoxine), and $\mathrm{Al}^{3+}$ blocked the Zn-induced death of GT1-7 cells $[86,87,89]$. We also found that intracellular $\mathrm{Ca}^{2+}$ levels $\left(\left[\mathrm{Ca}^{2+}\right]_{\mathrm{i}}\right)$ are increased after exposure to $\mathrm{Zn}$. The preadministration of $\mathrm{Al}^{3+}$, $\mathrm{a} \mathrm{Ca}^{2+}$ channel blocker, inhibited the $\mathrm{Zn}$-induced rise in $\left[\mathrm{Ca}^{2+}\right]_{\mathrm{i}}$ and attenuated $\mathrm{Zn}$-induced neurotoxicity. Thus, it is highly possible that $\mathrm{Ca}^{2+}$ homeostasis is implicated in $\mathrm{Zn}$ neurotoxicity pathways.

\subsection{Protective Substances against Zn-Induced Neuronal Death}

Considering the significance of $\mathrm{Zn}$ in the pathogenesis of $\mathrm{VD}$, it is highly possible that substances that inhibit Zn-induced neurotoxicity may become candidate drugs for the prevention or treatment of VD. Thus, we developed an assay system for screening such substances using GT1-7 cells and examined various agricultural products (such as fruits, vegetables, fish, and sea-products) [90]. Among the compounds tested, we found that the water-soluble extract of muscle tissue of Japanese eel (Anguilla japonica) exerted marked protective activity [91]. This activity was not diminished when the extract was boiled at $95{ }^{\circ} \mathrm{C}$ for $30 \mathrm{~min}$. We separated the heated extract using HPLC and determined the structure of the active fraction as that of carnosine using liquid chromatography mass spectrometry (LC-MS). Moreover, we found the protective activities in the extract of mango fruits (Mangifera indica) and in the extract of round herring (Etrumeus teres), and determined the active fraction as pyruvate and histidine, respectively $[92,93]$.

\subsection{The Protective Roles of Carnosine}

We investigated the neuroprotective mechanism of carnosine, and firstly focused on $\mathrm{Zn}$ translocation since carnosine can chelate $\mathrm{Zn}$. First, we analysed intracellular $\mathrm{Zn}^{2+}$ levels $\left(\left[\mathrm{Zn}^{2+}\right]_{\mathrm{i}}\right)$ in Zn-treated GT1-7 cells using Zn-specific fluorescent dye, ZnAF-2. However, neither carnosine nor anserine inhibited Zn influx into GT1-7 cells, whereas treatment with Ca-EDTA, a membrane impermeable chelator, decreased $\left[\mathrm{Zn}^{2+}\right]_{\mathrm{i}}[94]$. Thus, it is plausible that carnosine did not act as a $\mathrm{Zn}$ chelator and protect neurons from $\mathrm{Zn}$-induced neurotoxicity.

Second, we have analyzed the genetic changes induced by $\mathrm{Zn}$, and our real-time polymerase chain reaction (RT-PCR) analysis revealed that Zn caused the upregulation of several genes, including metal-related genes (MT-1, MT-2, ZnT-1), ER-stress related genes (GADD (growth-arrest- and DNA-damage-inducible gene) 34, GADD45, p8, CHOP (CCAAT-enhancer-binding protein homologous protein)), and a $\mathrm{Ca}^{2+}$-related gene $(A r c)$. Although carnosine is able to chelate $\mathrm{Zn}^{2+}$, we demonstrated that carnosine did not influence the intracellular concentration of $\mathrm{Zn}$ nor the $\mathrm{Zn}$-induced upregulation of MT-1 or ZnT-1. Meanwhile, carnosine was found to inhibit the upregulation of ER stress-related genes such as $G A D D 34, \mathrm{GADD} 45, \mathrm{CHOP}, \mathrm{Ca}^{2+}$ homeostasis-related genes such as activity-regulated cytoskeleton-associated protein $(A r c)$. We also found that carnosine attenuated neurodegenerations induced by the ER-stressor such as thapsigargin and tunicamycin, and/or induced by hydrogen peroxide $\left(\mathrm{H}_{2} \mathrm{O}_{2}\right)$. We demonstrated that anserine also attenuated $\mathrm{Zn}$-induced neurotoxicity, as well as carnosine. Furthermore, we recently found that sub-lethal concentrations of $\mathrm{Cu}^{2+}$ strongly enhance $\mathrm{Zn}^{2+}$-induced neurotoxicity and the expression of ER stress-related genes [95]. The $\mathrm{Cu}^{2+}$ enhanced $\mathrm{Zn}^{2+}$-induced neurotoxicity was attenuated by pyruvate and thioredoxin-albumin fusion protein $[96,97]$. Taken together, we hypothesize the possible molecular mechanisms underlying $\mathrm{Zn}$ neurotoxicity and the action of carnosine (Figure 5). After exposure to $\mathrm{Zn}$, intracellular $\mathrm{Zn}$ levels increase for at least $30 \mathrm{~min}$. Chelators such as Ca-EDTA block this process. Zn leads to an increase in intracellular $\mathrm{Ca}^{2+}$ levels and then triggers ER stress. This process is inhibited by $\mathrm{Al}^{3+}$ and other $\mathrm{Ca}^{2+}$ channel blockers. Zn triggers the inhibition of the energy production machinery in the mitochondria and the production of oxidative stress. The energy substrates pyruvate and citrate prevent this process. The oxidative stress was attenuated by the thioredoxin-albumin fusion protein. Finally, these three processes trigger neurodegenerative pathways and lead to the neuronal death observed in VD. Carnosine, released from glial cells, enters neurons by peptide transporters and inhibits $\mathrm{Zn}$-induced ER stress. Numerous in vivo studies have suggested that carnosine is protective against 
ischemia-induced neurodegeneration using experimental animals [98-100]. We have published a patent for carnosine to prevent or treat senile dementia based on the activities of carnosine [101].

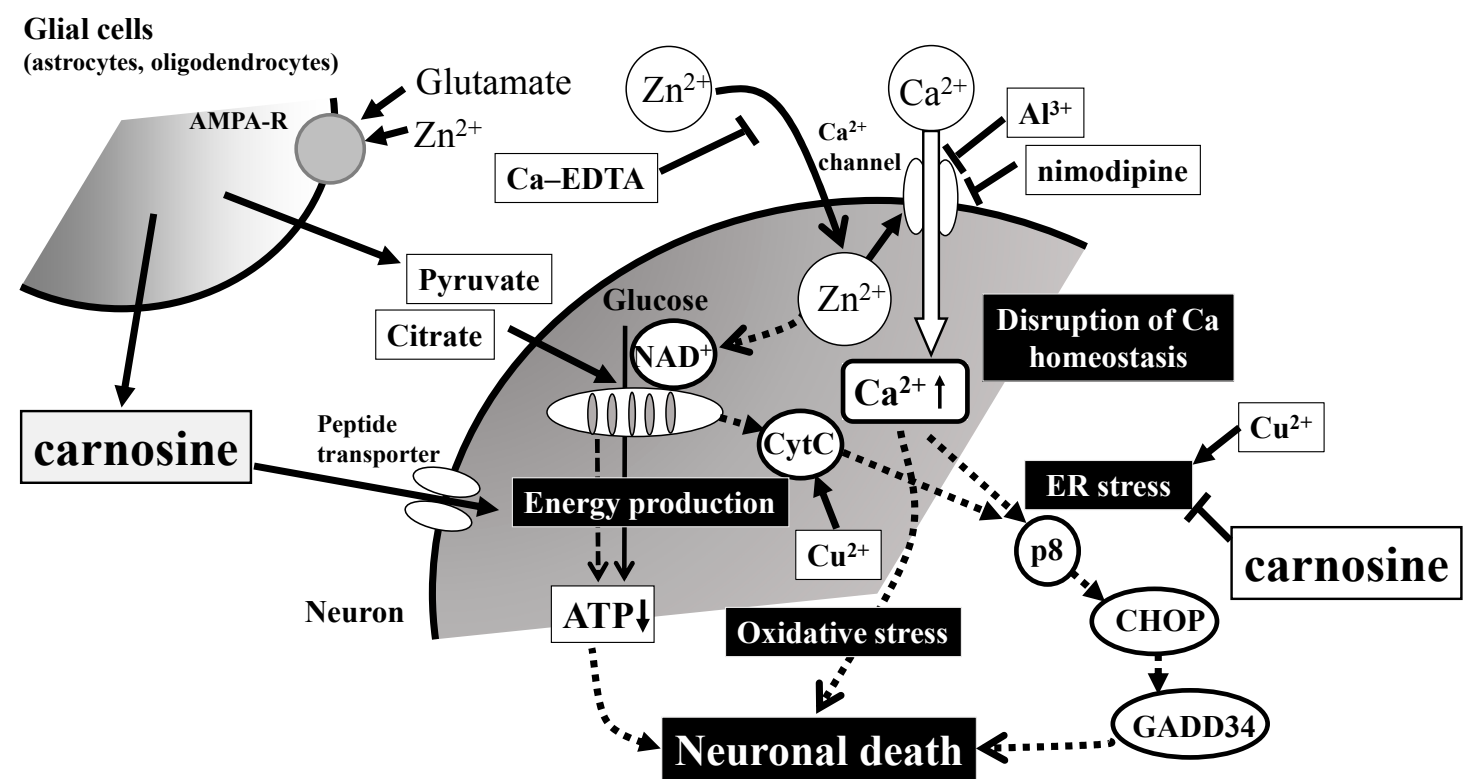

Figure 5. Possible molecular mechanisms underlying the protective effects of carnosine in preventing the neuronal death induced by Zn. Secreted excess amounts of Zn can translocate into cells and cause the disruption of $\mathrm{Ca}^{2+}$ homeostasis, energy failure in mitochondria, the induction of ER (reticulum) stress as well as oxidative stress, and apoptotic neuronal death. Carnosine is released into the synaptic cleft and is transported into cell bodies, where it can inhibit ER stress-related and/or Arc-related apoptotic pathways activated by $\mathrm{Zn}$. Details are shown in the text. Ca-EDTA: calcium ethylene diamine tetraacetic acid; $\mathrm{NAD}^{+}$: nicotinamide adenine dinucleotide; CytC: cytochrome C; ATP: adenosine triphosphate; $C H O P$ : CCAAT-enhancer-binding protein homologous protein; GADD34: growth-arrestand DNA-damage-inducible gene 34. AMPA-R: AMPA-type glutamate receptor.

\section{Zinc, Carnosine, and Prion Diseases}

\subsection{Zinc, Copper and Prion Diseases}

$\mathrm{Zn}$ and carnosine are also involved in prion diseases. Prion diseases include Creutzfeldt-Jakob disease (CJD), Gerstmann-Straussler-Scheinker syndrome (GSS), and Kuru disease in humans. They also include bovine spongiform encephalopathy (BSE) in cattle and scrapie in sheep [102]. Prion diseases are characterized by the spongiform degeneration of neurons and glial cells and the accumulation of amyloidogenic prion protein $(\operatorname{PrP})$. The administration of pathogenic tissue causes the characteristic infections, and thus, prion diseases are also called transmissible spongiform encephalopathies. During the transmissible infections, a normal prion protein $\left(\mathrm{PrP}^{\mathrm{C}}\right)$ is converted to an abnormal scrapie-type isoform $\left(\mathrm{PrPSc}^{\mathrm{Sc}}\right)$. Although both of $\mathrm{PrP}^{\mathrm{C}}$ and $\mathrm{PrP}^{\mathrm{Sc}}$ have the same primary sequence, $\mathrm{PrP}^{\mathrm{C}}$ differs from $\mathrm{PrP}^{\mathrm{Sc}}$ in that $\mathrm{PrP}^{\mathrm{Sc}}$ possesses a high content of $\beta$-sheet secondary structure compared to $\operatorname{PrP}^{\mathrm{C}}$, and therefore has resistance to protease digestion. $\operatorname{PrP}^{\mathrm{C}}$ is ubiquitously expressed throughout the entire body (Figure 6). It is speculated that the misfolded $\operatorname{PrP}^{\mathrm{Sc}}$ administrated from contaminated food induces normal $\mathrm{PrP}^{\mathrm{C}}$ molecules in the brain to misfold and aggregate.

Therefore, prion diseases are considered to be protein-misfolding diseases (conformational diseases), namely, the conformational change from $\operatorname{PrP}^{\mathrm{C}}$ to $\mathrm{PrP}^{\mathrm{Sc}}$ is crucial for the pathogenesis of prion diseases [103]. These features are similar to $\mathrm{AD}$. $\operatorname{PrP}^{\mathrm{C}}$ is reported to be a metalloprotein and regulates metal homeostasis [41]. $\operatorname{PrP}^{\mathrm{C}}$ is a 30-35-kDa glycoprotein and contains 208 amino acid residues. In its N-terminal, $\operatorname{PrPC}^{\mathrm{C}}$ possesses an octa-repeat domain composed of multiple tandem copies of the eight-residue sequence-PHGGGWGQ- The octa-repeat domain can bind four metal ions 
(including $\mathrm{Cu}^{2+}, \mathrm{Zn}^{2+}$, and other divalent ions), and two other histidine residues, His ${ }^{96}$ and His ${ }^{111}$, can bind two metal ions [104]. The levels of $\mathrm{Cu}$ in the brains of PrP-knockout mice were decreased compared with wild-type mice [105]. $\mathrm{PrP}^{\mathrm{C}}$ possesses protective roles against oxidative stress as $\mathrm{Cu} / \mathrm{Zn}$ superoxide dismutase $(\mathrm{Cu} / \mathrm{Zn} \mathrm{SOD})$ [106].

$\mathrm{Zn}^{2+}$ also binds $\operatorname{PrP}$, and can influence $\mathrm{Cu}$ binding to $\operatorname{PrP}^{\mathrm{C}}$. Moreover, prion genes and genes encoding ZIP transporters possess evolutionary sequence similarities [107]. Watt et al. hypothesized that $\operatorname{PrP}^{\mathrm{C}}$ acts as a ' $\mathrm{Zn}$ sensor' and facilitates the uptake of $\mathrm{Zn}$ into neurons by binding with AMPA receptors [108].

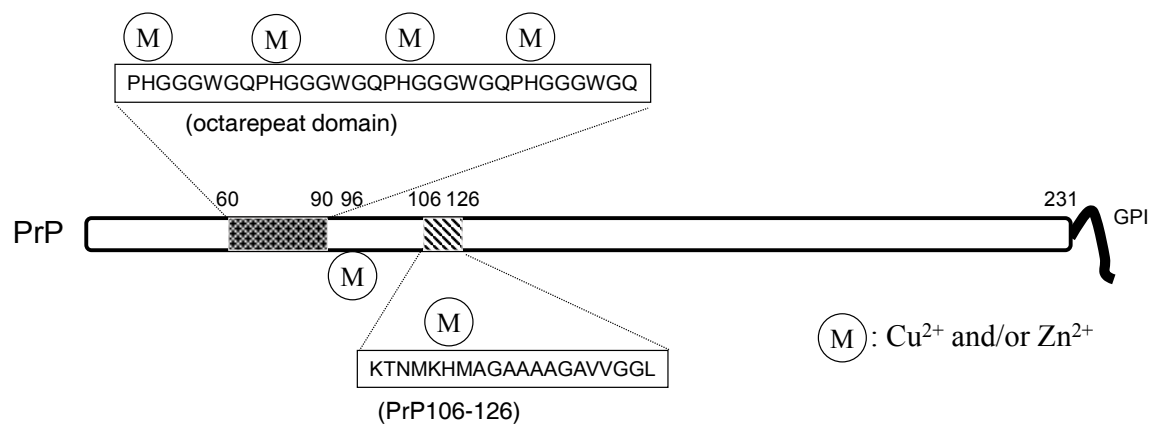

Figure 6. The structure of the prion protein. PrP: prion protein.

\subsection{Carnosine and $\operatorname{Pr}^{S \mathrm{Sc}}$-Induced Neurotoxicity}

Normal $\mathrm{PrPC}^{\mathrm{C}}$ has regulatory and neuroprotective functions such as regulating $\mathrm{Cu}$ homeostasis and antioxidant. Thus, loss of the protective functions by converting to $\mathrm{PrP}^{\mathrm{Sc}}$ will lead to neurodegeneration. Meanwhile, $\mathrm{PrP}^{\mathrm{Sc}}$ is neurotoxic. Since $\mathrm{PrP}^{\mathrm{Sc}}$ has strongly infectious characteristics, using a full-length prion protein is difficult [109]. Thus, we and other researchers have used synthetic fragment peptides of $\operatorname{PrP}(\mathrm{PrP} 106-126)$ in the study of $\mathrm{PrP}^{\mathrm{Sc}}$ neurotoxicity, owing to its similar characteristics with $\mathrm{PrP}^{\mathrm{Sc}}$ such as $\beta$-sheet formation, neurotoxicity, and metal-binding ability.

Our results using primary cultured rat hippocampal neurons and the thioflavin $\mathrm{T}$ (ThT) fluorescence method exhibited that PrP106-126 forms $\beta$-sheet structures during the "aging" process (incubation at $37^{\circ} \mathrm{C}$ for several days), and that aged PrP106-126 causes significant neurotoxicity. These characteristics are quite similar to A $\beta P$ [22]. Either $\mathrm{Zn}^{2+}$ or $\mathrm{Cu}^{2+}$ significantly attenuates PrP106-126 neurotoxicity. Furthermore, either $\mathrm{Zn}^{2+}$ or $\mathrm{Cu}^{2+}$ inhibits the oligomerization of PrP106-126 during the aging process, observed by thioflavin $\mathrm{T}$ fluorescence and atomic force microscopy observation.

Although chelators such as clioquinol and deferoxamine did not influence PrP106-126 neurotoxicity, we found that carnosine attenuates the neurotoxicity of PrP106-126 and inhibits oligomerization (Figure 7). Therefore, it is possible that carnosine acts as an anti-crosslinker of PrP106-126. Carnosine also inhibits the oligomerization of $\alpha$-synuclein, which is a major player in DLB and Parkinson's disease [110], and $\alpha$-crystalline in lens [111]. In this respect, the anti-crosslinking activity of carnosine is important for the protective functions of carnosine against these diseases. 

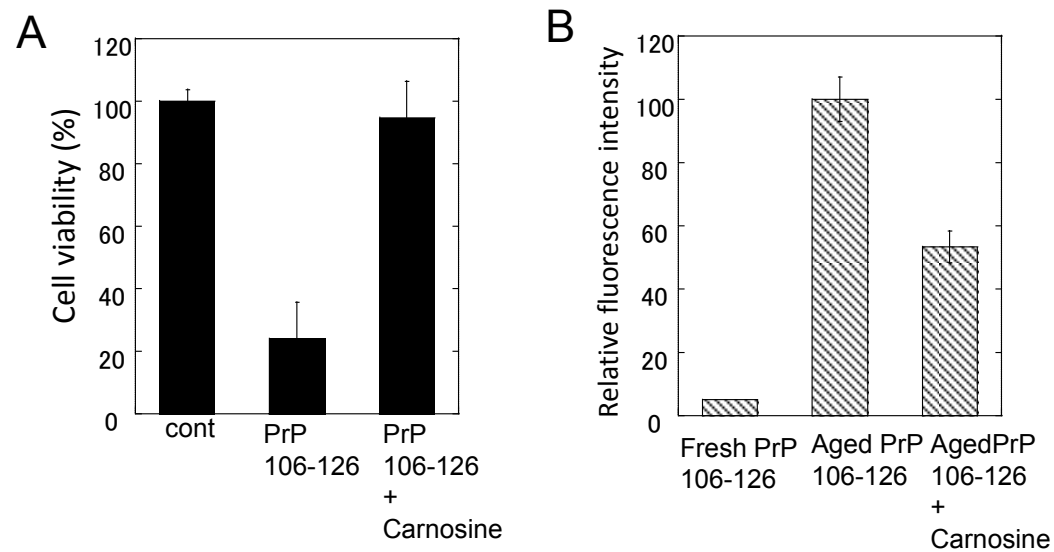

Figure 7. Effects of carnosine on the neurotoxicity and the conformational changes of PrP106-126. (A) Effects of carnosine on the neurotoxicity of PrP106-126. The viability of cultured rat hippocampal neurons was analyzed using the lactate dehydrogenase $(\mathrm{LDH})$ method after three days of exposure to $50 \mu \mathrm{M}$ PrP106-126 aged alone or with $1 \mathrm{mM}$ carnosine. Data are presented as mean \pm S.E.M. $(n=6)$; (B) Effects of carnosine on the thioflavin T (ThT) fluorescence of PrP106-126. The ThT fluorescence (ex. $490 \mathrm{~nm}$, em. $520 \mathrm{~nm}$ ) of $25 \mu \mathrm{M}$ of fresh PrP106-126 or aged PrP106-126 with $1 \mathrm{mM}$ carnosine was analyzed. Data are presented as mean \pm S.E.M. $(n=7)$.

\section{Crosstalk of Metals and Amyloidogenic Proteins at Synapse}

\subsection{Colocalization of APP and PrP at Synapse}

Synapses are small but critical nodes for information processing and memory formation in neural networks. Since synaptic plasticity is essential to memory formation, synaptic degenerations are primary observed in many neurodegenerative diseases. As discussed in the previous sections, metals $\left(\mathrm{Zn}^{2+}\right.$ or $\left.\mathrm{Cu}^{2+}\right)$ as well as neurotransmitters are co-released from synaptic vesicles into synaptic clefts. They bind to receptors at postsynaptic densities.

Two amyloidogenic proteins, APP and $\mathrm{PrP}^{\mathrm{C}}$, are localized in the synapse, and play essential roles in the regulation of metal homeostasis. APP is in the presynaptic region and $A \beta P$ is secreted into synaptic clefts in the presence of neuronal stimuli [112]. $\mathrm{PrP}^{\mathrm{C}}$ is coupled to glutamate receptors in the postsynaptic membranes [113]. Considering the short distance across the synaptic cleft (approximately $20 \mathrm{~nm}$ ), APP can interact with $\mathrm{PrP}^{\mathrm{C}}$ in this small compartment surrounded by a considerable amount of $\mathrm{Zn}^{2+}$ and $\mathrm{Cu}^{2+}$. Indeed, $\mathrm{PrP}^{\mathrm{C}}$ reportedly binds to $\mathrm{A} \beta \mathrm{P}$ oligomers and attenuates its neurotoxicity.

Given that the homeostasis of metals regulated by APP and $\operatorname{PrP}^{C}$ is disrupted, it triggers the degeneration of synapses, causing neurodegeneration and finally leading to the pathogenesis of these diseases. ZnT-1 is also localized in postsynaptic membranes and regulates $\mathrm{Zn}$ homeostasis by enhancing Zn efflux to the extracellular compartment [114]. ZnT-1 also regulates the activity of NMDA-type glutamate receptors. Meanwhile, $\mathrm{PrP}^{\mathrm{C}}$ controls $\mathrm{Zn}^{2+}$ influx into cells as an analogue of ZIP transporters, with AMPA-type glutamate receptors regulating synaptic $\mathrm{Zn}^{2+}$ levels. MT-3, brain specific metallothionein, may also regulate Zn homeostasis at synapses [115]. In addition, MT-3 is decreased in the brains of patients with AD [116].

\subsection{Carnosine: A Regulator of $\mathrm{Zn}$ and $\mathrm{Cu}$ in the Synapse}

Carnosine is another important contributor to regulating metal homeostasis in the synapse. The concentration of carnosine in the olfactory bulb is as high as $0.5 \mathrm{mM}$ [18]. Carnosine and homocarnosine is synthesized in glial cells, and carnosine-like immunoreactivity was observed in astrocytes or oligodendrocites [117]. Carnosine is reported to be secreted into the synaptic cleft from oligodendrocytes by glutamate in a Zn-dependent manner [36,118]. Therefore, carnosine is suggested to contribute the availability of $\mathrm{Zn}$ at the synapse and to control $\mathrm{Zn}$ homeostasis and, therefore, 
provides wide protection against various neurodegenerative disorders. Figure 8 exhibits a hypothetical scheme showing interactions between carnosine, APP, PrP, Zn, and $\mathrm{Cu}$ at the synapse.

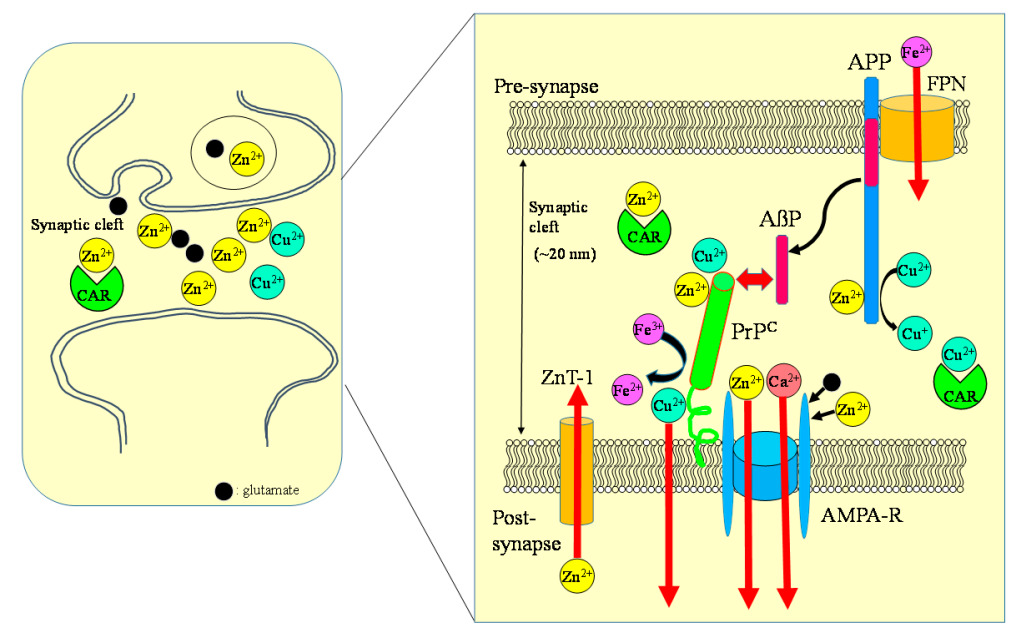

Figure 8. Crosstalk between carnosine, metals, APP, and PrP at the synapse. $\mathrm{Zn}, \mathrm{Cu}$, and glutamate accumulate in synaptic vesicles and are released into synaptic clefts during neuronal excitation. Under normal physiological conditions, APP binds $\mathrm{Cu}$ and regulates $\mathrm{Cu}$ levels by reducing $\mathrm{Cu}^{2+}$ to $\mathrm{Cu}^{+}$. The normal prion protein isoform $\mathrm{PrP}^{\mathrm{C}}$ binds to $\mathrm{Cu}$ at its $\mathrm{N}$-terminal domain and regulates synaptic $\mathrm{Cu}$ levels. It is possible that $\mathrm{PrP}^{\mathrm{C}}$ provides $\mathrm{Cu}$ to APP or to NMDA-type glutamate receptors, thereby influencing the production of $\mathrm{A} \beta \mathrm{P}$ or neuronal excitability. Both $\mathrm{APP}$ and $\mathrm{PrP}^{\mathrm{C}}$ reportedly attenuate $\mathrm{Cu}$-induced toxicity. $\mathrm{PrP}^{\mathrm{C}}$ also controls $\mathrm{Zn}^{2+}$ influx into the cells as an analogue of $\mathrm{ZIP}$ transporters, with AMPA-type glutamate receptors regulating synaptic $\mathrm{Zn}^{2+}$ levels. ZnT-1 is localized to postsynaptic membranes that express NMDA-type glutamate receptors and regulates $\mathrm{Zn}$ homeostasis. APP binds ferroportin (FPN) and regulates $\mathrm{Fe}^{2+}$ efflux. By contrast, $\mathrm{PrP}^{\mathrm{C}}$ acts as ferrireductase to regulate the $\mathrm{Fe}^{2+} / \mathrm{Fe}^{3+}$ ratio in synapses. The $\mathrm{Fe}^{2+}$ ions are transferred to enzymes, including neurotransmitter synthetases. Fe levels also regulate the expression of APP. It is plausible that carnosine binds to $\mathrm{Zn}^{2+}$ and $\mathrm{Cu}^{2+}$ and regulates homeostasis in these metals. ZnT-1: zinc transporter 1; NMDA-R: NMDA-type glutamate receptor; MT-3: metallothionein 3; CAR: carnosine.

\section{Carnosine in Foodstuffs}

Considering the beneficial and neuroprotective roles of carnosine, dietary supplementation with carnosine may become important for the prevention of various neurodegenerative diseases. The supplementation with carnosine/anserine improves the cognitive decline of AD model mice [119], or of elderly people [120]. Orally administered carnosine can cause increased carnosine levels in the brain [121]. Moreover, the amount of carnosine is age-dependently decreased [122].

Therefore, the quantitative analysis of carnosine in foods is essential for developing supplementation therapy. For this purpose, we established a convenient system for the analysis of carnosine and anserine in various foods using HPLC [123,124]. However, it is difficult to separate carnosine and anserine by performing reversed phase HPLC with a conventional octadecylsilyl (ODS) column used in ordinary peptide analysis, since carnosine and its analogues are highly hydrophilic and not retained in an ODS column. Thus, we used a carbon column (Hypercarb ${ }^{\mathrm{TM}}$ column; Thermo Electron Corp., Waltham, MA, USA) containing porous graphite carbon. The typical chromatograms of standard carnosine and anserine are shown in Figure 9A. Under these conditions, carnosine appeared at $5.7 \mathrm{~min}$ and anserine at $7.3 \mathrm{~min}$. We used conventional UV spectroscopy for measuring the absorbance at $215 \mathrm{~nm}$ to detect carnosine and anserine. The typical chromatograms of the water extract of chicken breast and the pork shoulder after being heated at $95^{\circ} \mathrm{C}$ for $30 \mathrm{~min}$ to reduce and remove proteins are shown in Figure 9B,C. The recovery rate of carnosine was determined to be $98.8 \pm 6.6 \%$ and that of anserine was $99.4 \pm 1.8 \%$ after this simple pretreatment. 
Using this method, the level of carnosine and anserine in food extracts was examined (Figure 10). Our results suggest that relatively high concentrations of carnosine exist in muscles. For example, $1 \mathrm{~g}$ of chicken muscle (breast) contained $2.16 \pm 0.67 \mathrm{mg} / \mathrm{g}$ (i.e., approximately $1 \mathrm{mM}$ ) of carnosine. The concentrations of carnosine and anserine were different among species and varied in various regions. These results coincide with previous studies [18].
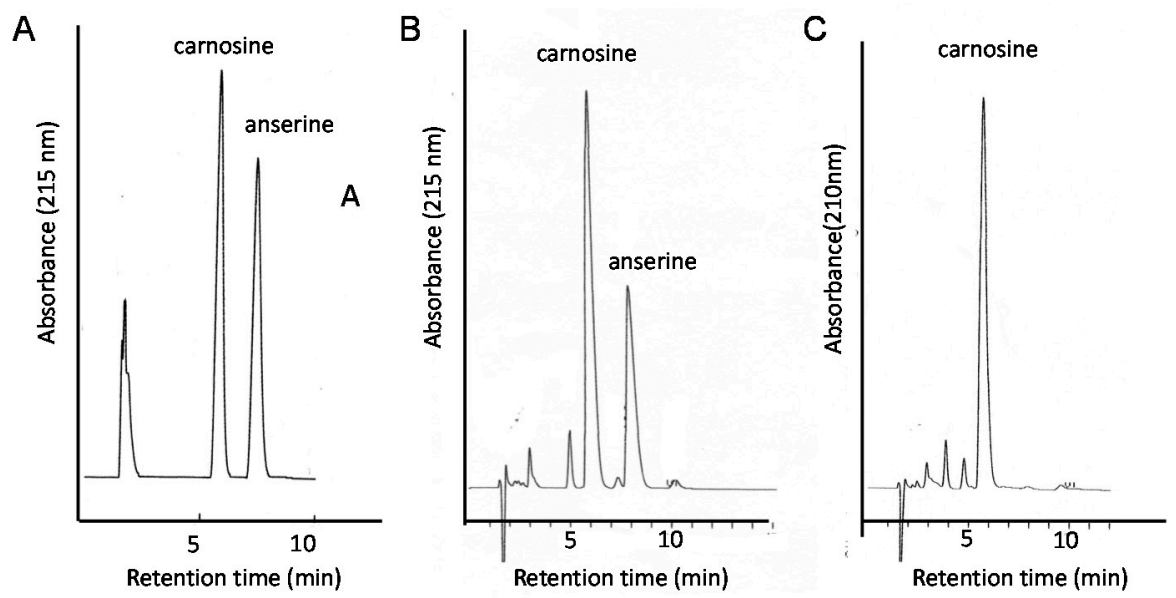

Figure 9. Typical chromatograms of the food extracts examined in this study. Standard solutions carnosine and anserine (A); extract of chicken breast (B), or extract of pork (C) were applied to the HPLC system equipped with a carbon column. Eluent: $0.05 \%$ TFA and $7 \% \mathrm{CH}_{3} \mathrm{CN}$; flow rate: $1.0 \mathrm{~mL} / \mathrm{min}$. The absorbance at $215 \mathrm{~nm}$ was observed.

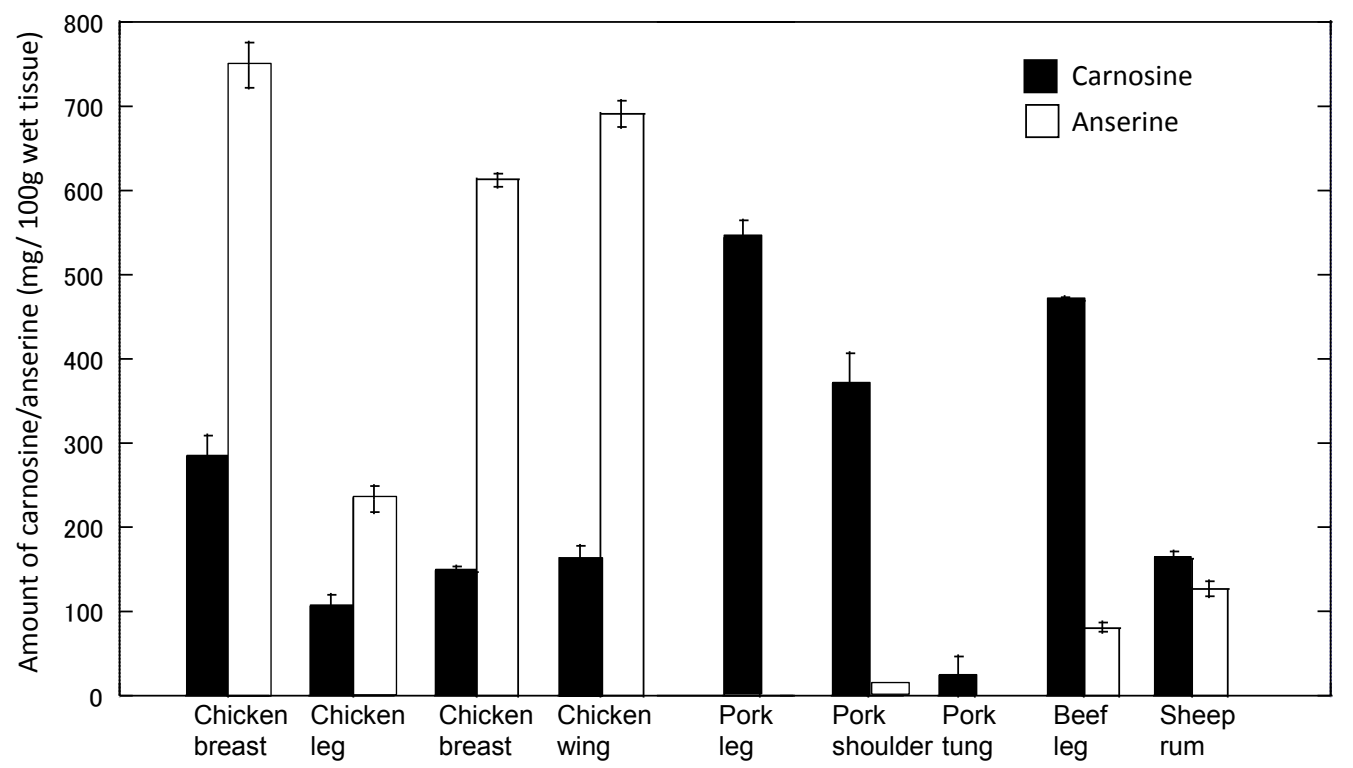

Figure 10. Levels of carnosine and anserine in various foods. The amount of carnosine and anserine of water-soluble extracts of various foods was analyzed by HPLC. Data are expressed as mean \pm S.E.M. $(n=3)$.

Furthermore, we analyzed the amount of carnosine in the muscle of thoroughbred horses and found that the gluteus medius exhibited the highest concentration of carnosine among five muscle tissues (flexor capri radius, triceps branchii, masseter, gluteus medius, sternocleidomastoid). Considering that the gluteus medius is abundant in Type IIa muscles and mainly used in high intensity exercise, carnosine may play essential roles in high intensity exercise. Indeed, the supplementation of 
$\beta$-alanine reportedly increases muscle carnosine concentrations and improves exercise performance, as concluded by the International Society of Sports Nutrition [125].

\section{Conclusions and Future Perspectives}

$\mathrm{Zn}$ plays critical roles in the pathogenesis of neurodegenerative diseases, such as $\mathrm{AD}, \mathrm{VD}$, and prion diseases. Although $\mathrm{Zn}$ acts as an enhancer of neurotoxicity as well as a protector in $\mathrm{AD}$ and $\mathrm{VD}$, it is possible that carnosine, a $\mathrm{Zn}$ chelator, acts as a neuroprotector in these diseases owing to its numerous beneficial characteristics including anti-ER stress, antioxidant, and anti-crosslink activities. Additionally, the properties of carnosine such as being water-soluble, heat-inactive, and nontoxic make it a good neuroprotective nutrient beneficial for health. Considering the beneficial characteristics of carnosine, dietary supplementation with carnosine or its component may become useful for health, as carnosine in food plays a critical role in the regulation of $\mathrm{Zn}$ homeostasis and the prevention of neurodegenerative diseases. Further research about the molecular mechanism of carnosine in preventing neurotoxicity is required.

Acknowledgments: This work was partially supported by a Grant-in Aid for Scientific Research from the Ministry of Education, Culture, Sports, Science, and Technology of Japan. (JSPS Kakennhi Grant No. 26460177). We thank N. Kobayashi for technical assistance.

Author Contributions: K.-i.T. and M.K. conceived and designed the experiments; K.-i.T. and M.K. conducted experiments. M.K. and M. K.-N. contributed to the writing of the manuscript.

Conflicts of Interest: The authors declare no conflicts of interest.

\section{Abbreviations}

$\begin{array}{ll}\text { AD } & \text { Alzheimer's disease } \\ \text { AMPA } & \text { amino-3-hydroxy-5-methyl-4-isoxazolepropionic acid } \\ \text { CSF } & \text { cerebrospinal fluid } \\ \text { EAR } & \text { estimated average } \\ \text { ER } & \text { endoplasmic reticulum } \\ \text { GABA } & \gamma \text {-aminobutyric acid } \\ \text { HPLC } & \text { high performance liquid chromatography } \\ \text { NMDA } & N \text {-methyl-d-aspartate } \\ \text { VD } & \text { vascular type of senile dementia } \\ \text { ZIP } & \text { Zrt-, Irt-like protein }\end{array}$

\section{References}

1. Ackland, M.L.; Michalczyk, A.A. Zinc and infant nutrition. Arch. Biochem. Biophys. 2016, 611, 51-57. [CrossRef] [PubMed]

2. Wessels, I.; Maywald, M.; Rink, L. Zinc as a gatekeeper of immune function. Nutrients 2017, 9, 1286. [CrossRef] [PubMed]

3. Hojyo, S.; Fukada, T. Roles of Zinc signaling in the immune system. J. Immunol. Res. 2016, 2016. [CrossRef] [PubMed]

4. Andreini, C.; Banci, L.; Bertini, I.; Rosato, A. Counting the zinc-proteins encoded in the human genome. J. Proteome Res. 2006, 5, 196-201. [CrossRef] [PubMed]

5. Prasad, A.S. Impact of the discovery of human zinc deficiency on health. J. Am. Coll. Nutr. 2009, 28, 257-265. [CrossRef] [PubMed]

6. Hambidge, M. Human zinc deficiency. J. Nutr. 2000, 130, 1344S-1349S. [CrossRef] [PubMed]

7. Takeda, A.; Tamano, H. Subclinical zinc deficiency impairs human brain function. J. Trace Elem. Med. Biol. 2012, 26, 70-73.

8. Doboszewska, U.; Wlaź, P.; Nowak, G.; Radziwoń-Zaleska, M.; Cui, R.; Młyniec, K. Zinc in the monoaminergic theory of depression: Its relationship to neural plasticity. Neural Plast. 2017, 2017. [CrossRef] [PubMed] 
9. Udechukwu, M.C.; Collins, S.A.; Udenigwe, C.C. Prospects of enhancing dietary zinc bioavailability with food-derived zinc-chelating peptides. Food Funct. 2016, 7, 4137-4144. [CrossRef] [PubMed]

10. Yasuda, H.; Tsutsui, T. Infants and elderlies are susceptible to zinc deficiency. Sci. Rep. 2016, 6, 21850. [CrossRef] [PubMed]

11. World Health Organization. Zinc Supplementation and Growth in Children: Biological, Behavioural and Contextual Rationale. Available online: http:/ / www.who.int/elena/bbc/zinc_stunting/en/ (accessed on 21 January 2017).

12. Heintschel, M.; Heuberger, R. The potential role of zinc supplementation on pressure injury healing in older adults: A review of the literature. Wounds 2017, 29, 56-61. [PubMed]

13. Awotiwon, A.A.; Oduwole, O.; Sinha, A.; Okwundu, C.I. Zinc supplementation for the treatment of measles in children. Cochrane Database Syst. Rev. 2017, 6, CD011177. [CrossRef] [PubMed]

14. Heyneman, C.A. Zinc deficiency and taste disorders. Ann. Pharmacother. 1996, 30, 186-187. [CrossRef] [PubMed]

15. Ikeda, M.; Aiba, T.; Ikui, A.; Inokuchi, A.; Kurono, Y.; Sakagami, M.; Takeda, N.; Tomita, H. Taste disorders: A survey of the examination methods and treatments used in Japan. Acta Otolaryngol. 2009, 129, 1115-1120. [CrossRef]

16. Matsukura, T.; Tanaka, H. Applicability of zinc complex of L-carnosine for medical use. Biochemistry 2000, 65, 817-823. [PubMed]

17. Suzuki, H.; Mori, M.; Seto, K.; Miyazawa, M.; Kai, A.; Suematsu, M.; Yoneta, T.; Miura, S.; Ishii, H. Polaprezinc attenuates the Helicobacter pylori-induced gastric mucosal leucocyte activation in Mongolian gerbils-A study using intravital videomicroscopy. Aliment. Pharmacol. Ther. 2001, 15, 715-725. [CrossRef] [PubMed]

18. Boldyrev, A.A.; Aldini, G.; Derave, W. Physiology and pathophysiology of carnosine. Physiol. Rev. 2013, 93, 1803-1845. [CrossRef] [PubMed]

19. Hipkiss, A.R. On the relationship between energy metabolism, proteostasis, aging and Parkinson's disease: Possible causative role of methylglyoxal and alleviative potential of carnosine. Aging Dis. 2017, 8, 334-345. [CrossRef] [PubMed]

20. Corona, C.; Frazzini, V.; Silvestri, E.; Lattanzio, R.; La Sorda, R.; Piantelli, M.; Canzoniero, L.M.; Ciavardelli, D.; Rizzarelli, E.; Sensi, S.L. Effects of dietary supplementation of carnosine on mitochondrial dysfunction, amyloid pathology, and cognitive deficits in 3xTg-AD mice. PLoS ONE 2011, 6, e17971. [CrossRef] [PubMed]

21. Mizuno, D.; Kawahara, M. Carnosine: A possible drug for vascular dementia. J. Vasc. Med. Surg. $2014,2,3$. [CrossRef]

22. Kawahara, M.; Koyama, H.; Nagata, T.; Sadakane, Y. Zinc, copper, and carnosine attenuate neurotoxicity of prion fragment PrP106-126. Metallomics 2011, 3, 726-734. [CrossRef] [PubMed]

23. Chez, M.G.; Buchanan, C.P.; Aimonovitch, M.C.; Becker, M.; Schaefer, K.; Black, C.; Komen, J. Double-blind, placebo-controlled study of L-carnosine supplementation in children with autistic spectrum disorders. J. Child Neurol. 2002, 17, 833-837. [CrossRef] [PubMed]

24. Baraniuk, J.N.; El-Amin, S.; Corey, R.; Rayhan, R.; Timbol, C. Carnosine treatment for gulf war illness: A randomized controlled trial. Glob. J. Health Sci. 2013, 5, 69-81. [CrossRef] [PubMed]

25. Rokicki, J.; Li, L.; Imabayashi, E.; Kaneko, J.; Hisatsune, T.; Matsuda, H. Daily carnosine and anserine supplementation alters verbal episodic memory and resting state network connectivity in healthy elderly adults. Front. Aging Neurosci. 2015, 7, 219. [CrossRef] [PubMed]

26. Frederickson, C.J.; Suh, S.W.; Silva, D.; Frederickson, C.J.; Thompson, R.B. Importance of zinc in the central nervous system: The zinc-containing neuron. J. Nutr. 2000, 130, 1471S-1483S. [CrossRef] [PubMed]

27. Frederickson, C.J.; Klitenick, M.A.; Manton, W.I.; Kirkpatrick, J.B. Cytoarchitectonic distribution of zinc in the hippocampus of man and the rat. Brain Res. 1983, 27, 335-339. [CrossRef]

28. Sensi, S.L.; Paoletti, P.; Koh, J.Y.; Aizenman, E.; Bush, A.I.; Hershfinkel, M. The neurophysiology and pathology of brain zinc. J. Neurosci. 2011, 31, 16076-16085. [CrossRef] [PubMed]

29. Ueno, S.; Tsukamoto, M.; Hirano, T.; Kikuchi, K.; Yamada, M.K.; Nishiyama, N.; Nagano, T.; Matsuki, N.; Ikegaya, Y. Mossy fiber $\mathrm{Zn}^{2+}$ spillover modulates heterosynaptic $\mathrm{N}$-methyl-D-aspartate receptor activity in hippocampal CA3 circuits. J. Cell Biol. 2002, 158, 215-220. [CrossRef] [PubMed]

30. Takeda, A.; Nakamura, M.; Fujii, H.; Tamano, H. Synaptic $\mathrm{Zn}^{2+}$ homeostasis and its significance. Metallomics 2013, 5, 417-423. [CrossRef] [PubMed] 
31. Wang, X.; Sommer, F.T.; Hirsch, J.A. Inhibitory circuits for visual processing in thalamus. Curr. Opin. Neurobiol. 2011, 21, 726-733. [CrossRef] [PubMed]

32. D'Ambrosi, N.; Rossi, L. Copper at synapse: Release, binding and modulation of neurotransmission. Neurochem. Int. 2015, 90, 36-45. [CrossRef] [PubMed]

33. Schikorski, T.; Stevens, C.F. Quantitative ultrastructural analysis of hippocampal excitatory synapses. J. Neurosci. 1997, 17, 5858-5867. [PubMed]

34. Vogt, K.; Mellor, J.; Tong, G.; Nicoll, R. The actions of synaptically released zinc at hippocampal mossy fiber synapses. Neuron 2000, 26, 187-196. [CrossRef]

35. Hopt, A.; Korte, S.; Fink, H.; Panne, U.; Niessner, R.; Jahn, R.; Herms, J. Methods for studying synaptosomal copper release. J. Neurosci. Methods 2003, 128, 159-172. [CrossRef]

36. Bauer, K. Carnosine and homocarnosine, the forgotten, enigmatic peptides of the brain. Neurochem. Res. 2005, 30, 1339-1345. [CrossRef] [PubMed]

37. Bolognin, S.; Cozzi, B.; Zambenedetti, P.; Zatta, P. Metallothioneins and the central nervous system: From a deregulation in neurodegenerative diseases to the development of new therapeutic approaches. J. Alzheimers Dis. 2014, 41, 29-42. [PubMed]

38. Fukada, T.; Kambe, T. Molecular and genetic features of zinc transporters in physiology and pathogenesis. Metallomics 2011, 3, 662-674. [CrossRef] [PubMed]

39. Bin, B.H.; Fukada, T.; Hosaka, T.; Yamasaki, S.; Ohashi, W.; Hojyo, S.; Miyai, T.; Nishida, K.; Yokoyama, S.; Hirano, T. Biochemical characterization of human ZIP13 protein: A homo-dimerized zinc transporter involved in the spondylocheiro dysplastic ehlers-danlos syndrome. J. Biol. Chem. 2011, 286, 40255-40265. [CrossRef] [PubMed]

40. Kawahara, M.; Mizuno, D.; Koyama, H.; Konoha, K.; Ohkawara, S.; Sadakane, Y. Disruption of zinc homeostasis and the pathogenesis of senile dementia. Metallomics 2013, 6, 209-219. [CrossRef] [PubMed]

41. Mizuno, D.; Koyama, H.; Ohkawara, S.; Sadakane, Y.; Kawahara, M. Involvement of trace elements in the pathogenesis of prion diseases. Curr. Pharam. Biotechnol. 2014, 15, 1049-1057. [CrossRef]

42. Sirangelo, I.; Iannuzzi, C. The role of metal binding in the amyotrophic lateral sclerosis-related aggregation of copper-zinc superoxide dismutase. Molecules 2017, 22, 1429. [CrossRef] [PubMed]

43. Kawahara, M.; Kato-Negishi, M.; Tanaka, K. Cross talk between neurometals and amyloidogenic proteins at the synapse and the pathogenesis of neurodegenerative diseases. Metallomics 2017, 9, 619-633. [CrossRef] [PubMed]

44. Selkoe, D.J. The molecular pathology of Alzheimer's disease. Neuron 1991, 6, 487-498. [CrossRef]

45. Hardy, J.A.; Higgins, G.A. Alzheimer's disease: The amyloid cascade hypothesis. Science 1992, 256, $184-185$. [CrossRef] [PubMed]

46. Wirths, O.; Multhaup, G.; Bayer, T.A. A modified $\beta$-amyloid hypothesis: Intraneuronal accumulation of the $\beta$-amyloid peptide-The first step of a fatal cascade. J. Neurochem. 2004, 91, 513-520. [CrossRef] [PubMed]

47. Goate, A.; Chartier-Harlin, M.C.; Mullan, M.; Brown, J.; Crawford, F.; Fidani, L.; Giuffra, L.; Haynes, A.; Irving, N.; James, L.; et al. Segregation of a missense mutation in the amyloid precursor protein gene with familial Alzheimer's disease. Nature 1991, 349, 704-706. [CrossRef] [PubMed]

48. Yankner, B.A.; Duffy, L.K.; Kirschner, D.A. Neurotropic and neurotoxic effects of amyloid $\beta$ protein: Reversal by tachykinin neuropeptides. Nature 1990, 250, 279-282.

49. Kawahara, M.; Negishi-Kato, M.; Sadakane, Y. Calcium dyshomeostasis and neurotoxicity of Alzheimer's beta-amyloid protein. Expert Rev. Neurother. 2009, 9, 681-693. [CrossRef] [PubMed]

50. Pike, C.J.; Walencewicz, A.J.; Glabe, C.G.; Cotman, C.W. In vitro aging of beta-amyloid protein causes peptide aggregation and neurotoxicity. Brain Res. 1991, 563, 311-314. [CrossRef]

51. Fukuyama, R.; Mizuno, T.; Mori, S.; Nakajima, K.; Fushiki, S.; Yanagisawa, K. Age-dependent change in the levels of $A \beta 40$ and $A \beta 42$ in cerebrospinal fluid from control subjects, and a decrease in the ratio of A $\beta 42$ to A $\beta 40$ level in cerebrospinal fluid from Alzheimer's disease patients. Eur. Neurol. 2000, 43, 155-160. [CrossRef] [PubMed]

52. Kawahara, M. Role of calcium dyshomeostasis via amyloid channels in the pathogenesis of Alzheimer's disease. Curr. Pharm. Des. 2010, 16, 2779-2789. [CrossRef] [PubMed]

53. Dyrks, T.; Dyrks, E.; Masters, C.L.; Beyreuther, K. Amyloidogenicity of rodent and human $\beta$ A4 sequences. FEBS Lett. 1993, 324, 231-236. [CrossRef] 
54. Bush, A.I.; Pettingell, W.H.; Multhaup, G.; d Paradis, M.; Vonsattel, J.P.; Gusella, J.F.; Beyreuther, K.; Masters, C.L.; Tanzi, R.E. Rapid induction of Alzheimer A- $\beta$ amyloid formation by zinc. Science 1994, 265, 1464-1467. [CrossRef] [PubMed]

55. Atwood, C.S.; Moir, R.D.; Huang, X.; Scarpa, R.C.; Bacarra, N.M.; Romano, D.M.; Hartshorn, M.A.; Tanzi, R.E.; Bush, A.I. Dramatic aggregation of Alzheimer $\mathrm{A} \beta$ by $\mathrm{Cu}(\mathrm{II})$ is induced by conditions representing physiological acidosis. J. Biol. Chem. 1998, 273, 12817-12826. [CrossRef] [PubMed]

56. Solomonov, I.; Korkotian, E.; Born, B.; Feldman, Y.; Bitler, A.; Rahimi, F.; Li, H.; Bitan, G.; Sagi, I. Zn²+-A $\beta 40$ complexes form metastable quasi-spherical oligomers that are cytotoxic to cultured hippocampal neurons. J. Biol. Chem. 2012, 287, 20555-20564. [CrossRef] [PubMed]

57. Chen, W.T.; Liao, Y.H.; Yu, H.M.; Cheng, I.H.; Chen, Y.R. Distinct effects of $\mathrm{Zn}^{2+}, \mathrm{Cu}^{2+}, \mathrm{Fe}^{3+}$, and $\mathrm{Al}^{3+}$ on amyloid-beta stability, oligomerization, and aggregation: Amyloid- $\beta$ destabilization promotes annular protofibril formation. J. Biol. Chem. 2011, 286, 9646-9656. [CrossRef] [PubMed]

58. Bolognin, S.; Zatta, P.; Lorenzetto, E.; Valenti, M.T.; Buffelli, M. $\beta$-Amyloid-aluminum complex alters cytoskeletal stability and increases ROS production in cortical neurons. Neurochem. Int. 2013, 62, 566-574. [CrossRef] [PubMed]

59. Sharma, A.K.; Pavlova, S.T.; Kim, J.; Kim, J.; Mirica, L.M. The effect of $\mathrm{Cu}^{2+}$ and $\mathrm{Zn}^{2+}$ on the A $\beta_{42}$ peptide aggregation and cellular toxicity. Metallomics 2013, 5, 1529-1536. [CrossRef] [PubMed]

60. Kawahara, M.; Kato, M.; Kuroda, Y. Effects of aluminum on the neurotoxicity of primary cultured neurons and on the aggregation of $\beta$-amyloid protein. Brain Res. Bull. 2001, 55, 211-217. [CrossRef]

61. Small, D.H.; Mok, S.S.; Bornstein, J.C. Alzheimer's disease and A $\beta$ toxicity: From top to bottom. Nat. Rev. Neurosci. 2001, 2, 595-598. [CrossRef] [PubMed]

62. Demuro, A.; Parker, I.; Stutzmann, G.E. Calcium signaling and amyloid toxicity in Alzheimer disease. J. Biol. Chem. 2010, 285, 12463-12468. [CrossRef] [PubMed]

63. Arispe, N.; Rojas, E.; Pollard, H.B. Alzheimer disease amyloid $\beta$ protein forms calcium channels in bilayer membranes: Blockade by tromethamine and aluminum. Proc. Natl. Acad. Sci. USA 1993, 90, 567-571. [CrossRef] [PubMed]

64. Kawahara, M.; Arispe, N.; Kuroda, Y.; Rojas, E. Alzheimer's disease amyloid $\beta$-protein forms $\mathrm{Zn}^{2+}$-sensitive, cation-selective channels across excised membrane patches from hypothalamic neurons. Biophys. J. 1997, 73, 67-75. [CrossRef]

65. Kawahara, M.; Arispe, N.; Kuroda, Y.; Rojas, E. Alzheimer's $\beta$-amyloid, human islet amylin and prion protein fragment evoke intracellular free-calcium elevations by a common mechanism in a hypothalamic GnRH neuronal cell-line. J. Biol. Chem. 2000, 275, 14077-14083. [CrossRef] [PubMed]

66. Kawahara, M.; Ohtsuka, I.; Yokoyama, S.; Kato-Negishi, M.; Sadakane, Y. Membrane incorporation, channel formation, and disruption of calcium homeostasis by Alzheimer's $\beta$-amyloid protein. Int. J. Alzheimers Dis. 2011, 2011. [CrossRef]

67. Sepulveda, F.J.; Parodi, J.; Peoples, R.W.; Opazo, C.; Aguayo, L.G. Synaptotoxicity of Alzheimer $\beta$ amyloid can be explained by its membrane perforating property. PLOS ONE 2010, 27, e11820. [CrossRef] [PubMed]

68. Arispe, N.; Pollard, H.B.; Rojas, E. $\mathrm{Zn}^{2+}$ interactions with Alzheimer's amyloid $\beta$ protein calcium channels. Proc. Natl. Acad. Sci. USA 1996, 93, 1710-1715. [CrossRef] [PubMed]

69. Lin, H.; Bhatia, R.; Lal, R. Amyloid $\beta$ protein forms ion channels: Implications for Alzheimer's disease pathophysiology. FASEB J. 2001, 15, 2433-2444. [CrossRef] [PubMed]

70. Kepp, K.P. Alzheimer's disease due to loss of function: A new synthesis of the available data. Prog. Neurobiol. 2016, 143, 36-60. [CrossRef] [PubMed]

71. Wild, K.; August, A.; Pietrzik, C.U.; Kins, S. Structure and synaptic function of metal binding to the amyloid precursor protein and its proteolytic fragments. Front. Mol. Neurosci. 2017, 10, 21. [CrossRef] [PubMed]

72. Rogers, J.T.; Randall, J.D.; Cahill, C.M.; Eder, P.S.; Huang, X.; Gunshin, H.; Leiter, L.; McPhee, J.; Sarang, S.S.; Utsuki, T; et al. An iron-responsive element type II in the $5^{\prime}$-untranslated region of the Alzheimer's amyloid precursor protein transcript. J. Biol. Chem. 2002, 277, 45518-45528. [CrossRef] [PubMed]

73. Wong, B.X.; Tsatsanis, A.; Lim, L.Q.; Adlard, P.A.; Bush, A.I.; Duce, J.A. $\beta$-Amyloid precursor protein does not possess ferroxidase activity but does stabilize the cell surface ferrous iron exporter ferroportin. PLoS ONE 2014, 9, e114174. [CrossRef] [PubMed] 
74. Soto, C.; Sigurdsson, E.M.; Morelli, L.; Kumar, R.A.; Castaño, E.M.; Frangione, B. $\beta$-sheet breaker peptides inhibit fibrillogenesis in a rat brain model of amyloidosis: Implications for Alzheimer's therapy. Nat. Med. 1998, 4, 822-826. [CrossRef] [PubMed]

75. Babizhayev, M.A. Antioxidant activity of L-carnosine, a natural histidine-containing dipeptide in crystalline lens. Biochim. Biophys. Acta 1989, 1004, 363-371. [CrossRef]

76. Dubois, V.D.; Bastawrous, A. N-acetylcarnosine (NAC) drops for age-related cataract. Cochrane Database Syst. Rev. 2017, 2, CD009493. [CrossRef] [PubMed]

77. Aloisi, A.; Barca, A.; Romano, A.; Guerrieri, S.; Storelli, C.; Rinaldi, R.; Verri, T. Anti-aggregating effect of the naturally occurring dipeptide carnosine on A $\beta 1-42$ fibril formation. PLoS ONE 2013, 8, e68159. [CrossRef] [PubMed]

78. Attanasio, F.; Convertino, M.; Magno, A.; Caflisch, A.; Corazza, A.; Haridas, H.; Esposito, G.; Cataldo, S.; Pignataro, B.; Milardi, D.; et al. Carnosine inhibits A $\beta 42$ aggregation by perturbing the H-bond network in and around the central hydrophobic cluster. ChemBioChem 2013, 14, 583-592. [CrossRef] [PubMed]

79. Fonteh, A.N.; Harrington, R.J.; Tsai, A.; Liao, P.; Harrington, M.G. Free amino acid and dipeptide changes in the body fluids from Alzheimer's disease subjects. Amino Acids 2007, 32, 213-224. [CrossRef] [PubMed]

80. Choi, D.W. Calcium: Still center-stage in hypoxic-ischemic neuronal death. Trends Neurosci. 1995, 18, 58-60. [CrossRef]

81. Choi, D.W.; Koh, J.Y. Zinc and brain injury. Annu. Rev. Neurosci. 1998, 21, 347-375. [CrossRef] [PubMed]

82. Weiss, J.H.; Sensi, S.L.; Koh, J.Y. $\mathrm{Zn}^{2+}$ : A novel ionic mediator of neural injury in brain disease. Trends Pharmacol. Sci. 2000, 21, 395-401. [CrossRef]

83. Koh, J.Y.; Suh, S.W.; Gwag, B.J.; He, Y.Y.; Hsu, C.Y.; Choi, D.W. The role of zinc in selective neuronal death after transient global cerebral ischemia. Science 1996, 272, 1013-1016. [CrossRef] [PubMed]

84. Calderone, A.; Jover, T.; Mashiko, T.; Noh, K.M.; Tanaka, H.; Bennett, M.V.; Zukin, R.S. Late calcium EDTA rescues hippocampal CA1 neurons from global ischemia-induced death. J. Neurosci. 2004, 24, 9903-9913. [CrossRef] [PubMed]

85. Capasso, M.; Jeng, J.M.; Malavolta, M.; Mocchegiani, E.; Sensi, SL. Zinc dyshomeostasis: A key modulator of neuronal injury. J. Alzheimers Dis. 2005, 8, 93-108. [CrossRef] [PubMed]

86. Kawahara, M.; Kato-Negishi, M.; Kuroda, Y. Pyruvate blocks zinc-induced neurotoxicity in immortalized hypothalamic neurons. Cell. Mol. Neurobiol. 2002, 22, 87-93. [CrossRef] [PubMed]

87. Koyama, H.; Konoha, K.; Sadakane, Y.; Ohkawara, S.; Kawahara, M. Zinc neurotoxicity and the pathogenesis of vascular-type dementia: Involvement of calcium dyshomeostasis and carnosine. J. Clin. Toxicol. 2011, S3. [CrossRef]

88. Mellon, P.L.; Windle, J.J.; Goldsmith, P.C.; Padula, C.A.; Roberts, J.L.; Weiner, R.I. Immortalization of hypothalamic GnRH neurons by genetically targeted tumorigenesis. Neuron 1990, 5, 1-10. [CrossRef]

89. Konoha, K.; Sadakane, Y.; Kawahara, M. Effects of gadolinium and other metal on the neurotoxicity of immortalized hypothalamic neurons induced by zinc. Biomed. Res. Trace Elem. 2004, 15, 275-277.

90. Kawahara, M.; Konoha, K.; Nagata, T.; Sadakane, Y. Protective substances against zinc-induced neuronal death after ischemia: Carnosine a target for drug of vascular type of dementia. Recent Patents CNS Drug Discov. 2007, 2, 145-149. [CrossRef]

91. Sadakane, Y.; Konoha, K.; Nagata, T.; Kawahara, M. Protective activity of the extracts from Japanese eel (Anguilla japonica) against zinc-induced neuronal cell death: Carnosine and an unknown substance. Trace Nutr. Res. 2007, 24, 98-105.

92. Sadakane, Y.; Konoha, K.; Kawahara, M. Protective activity of mango (Mangifera indica L.) fruit against a zinc-induced neuronal cell death is independent of its antioxidant activity. Trace Nutr. Res. 2005, 22, 73-79.

93. Kawahara, M.; Sadakane, Y.; Koyama, H.; Konoha, K.; Ohkawara, S. D-histidine and L-histidine attenuate zinc-induced neuronal death in GT1-7 cells. Metallomics 2013, 5, 453-460. [CrossRef] [PubMed]

94. Mizuno, D.; Konoha-Mizuno, D.; Mori, M.; Sadakane, Y.; Koyama, H.; Ohkawara, S.; Kawahara, M. Protective activity of carnosine and anserine against zinc-induced neurotoxicity: A possible treatment for vascular dementia. Metallomics 2015, 7, 1233-1239. [CrossRef] [PubMed]

95. Tanaka, K.; Kawahara, M. Copper enhances zinc-induced neurotoxicity and the endoplasmic reticulum stress response in a neuronal model of vascular dementia. Front. Neurosci. 2017, 11, 58. [CrossRef] [PubMed] 
96. Tanaka, K.; Shimoda, M.; Kawahara, M. Pyruvic acid prevents $\mathrm{Cu}^{2+} / \mathrm{Zn}^{2+}$-induced neurotoxicity by suppressing mitochondrial injury. Biochem. Biophys. Res. Commun. 2018, 495, 1335-1341. [CrossRef] [PubMed]

97. Tanaka, K.; Shimoda, M.; Chuang, V.T.G.; Nishida, K.; Kawahara, M.; Ishida, T.; Otagiri, M.; Maruyama, T.; Ishima, Y. Thioredoxin-albumin fusion protein prevents copper enhanced zinc-induced neurotoxicity via its antioxidative activity. Int. J. Pharm. 2018, 535, 140-147. [CrossRef] [PubMed]

98. Rajanikant, G.K.; Zemke, D.; Senut, M.C.; Frenkel, M.B.; Chen, A.F.; Gupta, R.; Majid, A. Carnosine is neuroprotective against permanent focal cerebral ischemia in mice. Stroke 2007, 38, 3023-3031. [CrossRef] [PubMed]

99. Zhang, X.; Song, L.; Cheng, X.; Yang, Y.; Luan, B.; Jia, L.; Xu, F.; Zhang, Z. Carnosine pretreatment protects against hypoxia-ischemia brain damage in the neonatal rat model. Eur. J. Pharmacol. 2011, 667, 202-207. [CrossRef] [PubMed]

100. Davis, C.K.; Laud, P.J.; Bahor, Z.; Rajanikant, G.K.; Majid, A. Systematic review and stratified meta-analysis of the efficacy of carnosine in animal models of ischemic stroke. J. Cereb. Blood Flow Metab. 2016, 36, 1686-1694. [CrossRef] [PubMed]

101. Kawahara, M.; Konoha, K.; Nagata, T.; Sadakane, Y. A Drug for Prevention or Treatment for Vascular Dementia. JP5382633, 11 October 2013.

102. Prusiner, S.B. Prion diseases and the BSE crisis. Science 1997, 278, 245-251. [CrossRef] [PubMed]

103. Carrell, R.W.; Lomas, D.A. Conformational disease. Lancet 1997, 350, 134-138. [CrossRef]

104. Jackson, G.S.; Murray, I.; Hosszu, L.L.; Gibbs, N.; Waltho, J.P.; Clarke, A.R.; Collinge, J. Location and properties of metal-binding sites on the human prion protein. Proc. Natl. Acad. Sci. USA 2001, 98, 8531-8535. [CrossRef] [PubMed]

105. Brown, D.R.; Qin, K.; Herms, J.W.; Madlung, A.; Manson, J.; Strome, R.; Fraser, P.E.; Kruck, T.; von Bohlen, A.; Schulz-Schaeffer, W.; et al. The cellular prion protein binds copper in vivo. Nature 1997, 390, 684-687. [CrossRef] [PubMed]

106. Brown, D.R. Brain proteins that mind metals: A neurodegenerative perspective. Dalton Trans. 2009, 21, 4069-4076. [CrossRef] [PubMed]

107. Schmitt-Ulms, G.; Ehsani, S.; Watts, J.C.; Westaway, D.; Wille, H. Evolutionary descent of prion genes from the ZIP family of metal ion transporters. PLoS ONE 2009, 4, e7208. [CrossRef] [PubMed]

108. Watt, N.T.; Griffiths, H.H.; Hooper, N.M. Neuronal zinc regulation and the prion protein. Prion 2013, 7, 203-208. [CrossRef] [PubMed]

109. Bonetto, V.; Massignan, T.; Chiesa, R.; Morbin, M.; Mazzoleni, G.; Diomede, L.; Angeretti, N.; Colombo, L.; Forloni, G.; Tagliavini, F.; et al. Synthetic miniprion PrP106. J. Biol. Chem. 2002, 277, 31327-31334. [CrossRef] [PubMed]

110. Kang, J.H.; Kim, K.S. Enhanced oligomerization of the alpha-synuclein mutant by the Cu, Zn-superoxide dismutase and hydrogen peroxide system. Mol. Cells 2003, 15, 87-93. [PubMed]

111. Villari, V.; Attanasio, F.; Micali, N. Control of the structural stability of $\alpha$-crystallin under thermal and chemical stress: The role of carnosine. J. Phys. Chem. B 2014, 118, 13770-13776. [CrossRef] [PubMed]

112. Del Prete, D.; Lombino, F.; Liu, X.; D'Adamio, L. APP is cleaved by Bace1 in pre-synaptic vesicles and establishes a pre-synaptic interactome, via its intracellular domain, with molecular complexes that regulate pre-synaptic vesicles functions. PLoS ONE 2014, 9, e108576. [CrossRef] [PubMed]

113. Stys, P.K.; You, H.; Zamponi, G.W. Copper-dependent regulation of NMDA receptors by cellular prion protein: Implications for neurodegenerative disorders. J. Physiol. 2012, 590, 1357-1368. [CrossRef] [PubMed]

114. Mellone, M.; Pelucchi, S.; Alberti, L.; Genazzani, A.A.; Di Luca, M.; Gardoni, F. Zinc transporter-1: A novel NMDA receptor-binding protein at the postsynaptic density. J. Neurochem. 2015, 132, 159-168. [CrossRef] [PubMed]

115. Howells, C.; West, A.K.; Chung, R.S. Neuronal growth-inhibitory factor (metallothionein-3): Evaluation of the biological function of growth-inhibitory factor in the injured and neurodegenerative brain. FEBS J. 2010, 277, 2931-2939. [CrossRef] [PubMed]

116. Uchida, Y.; Takio, K.; Titani, K.; Thara, Y.; Tomonaga, M. The growth inhibitory factor that is deficient in the Alzheimer's disease brain is a 68 amino acid metallothionein-like protein. Neuron 1991, 7, 337-347. [CrossRef] 
117. De Marchis, S.; Modena, C.; Peretto, P.; Migheli, A.; Margolis, F.L.; Fasolo, A. Carnosine-related dipeptides in neurons and glia. Biochemistry 2000, 65, 824-833. [PubMed]

118. Bakardjiev, A. Carnosine and $\beta$-alanine release is stimulated by glutamatergic receptors in cultured rat oligodendrocytes. Glia 1998, 24, 346-351. [CrossRef]

119. Kaneko, J.; Enya, A.; Enomoto, K.; Ding, Q.; Hisatsune, T. Anserine (beta-alanyl-3-methyl-L-histidine) improves neurovascular-unit dysfunction and spatial memory in aged A $\beta$ PPswe/PSEN1dE9 Alzheimer's-model mice. Sci. Rep. 2017, 7, 12571. [CrossRef] [PubMed]

120. Hisatsune, T.; Kaneko, J.; Kurashige, H.; Cao, Y.; Satsu, H.; Totsuka, M.; Katakura, Y.; Imabayashi, E.; Matsuda, H. Effect of anserine/carnosine supplementation on verbal episodic memory in elderly people. J. Alzheimers Dis. 2016, 50, 149-159. [CrossRef] [PubMed]

121. Tomonaga, S.; Hayakawa, T.; Yamane, H.; Maemura, H.; Sato, M.; Takahata, Y.; Morimatsu, F.; Furuse, M. Oral administration of chicken breast extract increases brain carnosine and anserine concentrations in rats. Nutr. Neurosci. 2007, 10, 181-186. [CrossRef] [PubMed]

122. Stuerenburg, H.J. The roles of carnosine in aging of skeletal muscle and in neuromuscular diseases. Biochemistry 2000, 65, 862-865. [PubMed]

123. Mori, M.; Mizuno, D.; Konoha-Mizuno, K.; Sadakane, Y.; Kawahara, M. Quantitative analysis of carnosine and anserine in foods by performing high performance liquid chromatography. Biomed. Res. Trace Elem. 2015, 26, 147-152.

124. Mori, M.; Mizuno, D.; Konoha-Mizuno, K.; Sadakane, Y.; Kawahara, M. Carnosine concentration in the muscle of thoroughbred horses and its implications in exercise performance. Trace Nutr. Res. 2015, 32, 49-53.

125. Trexler, E.T.; Smith-Ryan, A.E.; Stout, J.R.; Hoffman, J.R.; Wilborn, C.D.; Sale, C.; Kreider, R.B.; Jäger, R.; Earnest, C.P.; Bannock, L.; et al. International society of sports nutrition position stand: Beta-Alanine. J. Int. Soc. Sports Nutr. 2015, 12, 30. [CrossRef] [PubMed]

(C) 2018 by the authors. Licensee MDPI, Basel, Switzerland. This article is an open access article distributed under the terms and conditions of the Creative Commons Attribution (CC BY) license (http://creativecommons.org/licenses/by/4.0/). 